Article

\title{
Kinetics, Mechanism and Theoretical Studies of Norbornene-Ethylene Alternating Copolymerization Catalyzed by Organopalladium(II) Complexes Bearing Hemilabile $\alpha$-Amino-pyridine
}

\author{
Kuo-Hsuan Yu ${ }^{1}$, Shou-Ling Huang ${ }^{1}$, Yi-Hung Liu ${ }^{1}$, Yu Wang ${ }^{1}$, Shiuh-Tzung Liu ${ }^{1}$, \\ Yuan-Chung Cheng ${ }^{1, *}$, Ya-Fan Lin ${ }^{1,2, *}$ (D) and Jwu-Ting Chen ${ }^{1, *}$ \\ 1 Department of Chemistry, National Taiwan University, Taipei 10617, Taiwan; \\ d96223126@ntu.edu.tw (K.-H.Y.); shouling@ntu.edu.tw (S.-L.H); yuliu@ntu.edu.tw (Y.-H.L.); \\ wangyu@ntu.edu.tw (Y.W.); stliu@ntu.edu.tw (S.-T.L.) \\ 2 Department of Medicinal and Applied Chemistry, Kaohsiung Medical University, Kaohsiung 80708, Taiwan \\ * Correspondence: yuanchung@ntu.edu.tw (Y.-C.C.); yafan@kmu.edu.tw (Y.-F.L.); jtchen@ntu.edu.tw (J.-T.C.); \\ Tel.: +886-2-3366-9788 (Y.-C.C.); +886-7-312-1101 ext. 2374 (Y.-F.L.); +886-2-3366-1659 (J.-T.C.)
}

Received: 2 June 2017; Accepted: 27 June 2017; Published: 30 June 2017

\begin{abstract}
Cationic methylpalladium complexes bearing hemilabile bidentate $\alpha$-amino-pyridines can serve as effective precursors for catalytic alternating copolymerization of norbornene $(\mathrm{N})$ and ethylene (E), under mild conditions. The norbornyl palladium complexes in the formula of $\left\{\left[\mathrm{RHNCH} \mathrm{H}_{2}\left(0-\mathrm{C}_{6} \mathrm{H}_{4} \mathrm{~N}\right)\right] \mathrm{Pd}\left(\mathrm{C}_{7} \mathrm{H}_{10} \mathrm{Me}\right)(\mathrm{NCMe})\right\}\left(\mathrm{BF}_{4}\right)\left(\mathrm{R}={ }^{i} \operatorname{Pr}(\mathbf{2 a}),{ }^{t} \mathrm{Bu}(\mathbf{2 b}), \operatorname{Ph}(\mathbf{2 c}), 2,6-\mathrm{Me}_{2} \mathrm{C}_{6} \mathrm{H}_{3}\right.$ (2d), 2,6- $\left.{ }^{i} \mathrm{Pr}_{2} \mathrm{C}_{6} \mathrm{H}_{3}(\mathbf{2 e})\right)$ were synthesized via single insertion of norbornene into the corresponding methylpalladium complexes 1a-1e, respectively. Both square planar methyl and norbornyl palladium complexes exhibit facile equilibria of geometrical isomerization, via sterically-controlled amino decoordination-recoordination of amino-pyridine. Kinetic studies of E-insertion, N-insertion of complexes $\mathbf{1}$ and 2, and the geometric isomerization reactions have been examined by means of VT-NMR, and found in excellent agreement with the results estimated by DFT calculations. The more facile $\mathrm{N}$-insertion in the cis-isomers, and ready geometric isomerization, cooperatively lead to a new mechanism that accounts for the novel catalytic formation of alternating COC.
\end{abstract}

Keywords: Norbornene-ethylene alternating copolymerization; hemilabile; amino-pyridine; palladium; geometrical isomerism; kinetics; mechanism

\section{Introduction}

Cyclic olefin copolymers (COC) have demonstrated wide-range applications in the industries of coating, packaging, medical equipment, etc. [1-6], because of their high $\mathrm{T}_{\mathrm{g}}$, high transparency, low dielectric constants, and good biocompatibility and processability [7-16]. These physical properties are usually controlled by the compositions and the microstructures of the monomers, resulting from the design of the catalysts [17-36]. For instance, with the assistance of methylaluminoxane (MAO) [17,37-50], most of the early-transition-metal metallocene derivatives catalyzed copolymerization to afford random E-N products. The ligand steric hindrance readily impedes the norbornene insertion, and thus the PE segments are usually long. On the other hand, if the copolymerization is catalyzed by the non-metallocene titanium complexes, many examples provide an alternating microstructure for the E-N copolymer products [51-63].

Although late-transition metal catalysts have been employed to generate functionalized polyolefins [64-72], the successful examples to produce COC are still limited [73-79], because of the occurrence of $\beta-\mathrm{H}$ elimination on the alkyl chain. We previously reported our finding of the alternating 
E-N copolymerization, induced by methylpalladium(II) cations and bearing hemilabile bidentate ligand of $\alpha$-amino-pyridines without the assistance of MAO (as shown in Scheme 1) [80]. The general features of the copolymerization show $\mathrm{M}_{\mathrm{w}} \sim 10^{4}$, $\mathrm{PDI} \sim 1.5, \mathrm{~T}_{\mathrm{g}} \sim 100-120^{\circ} \mathrm{C}$, and characteristic $\mathrm{N} \% \sim 50$, indicating that the COCs have a predominated alternating E-N microstructure. Furthermore, the reactivity ratios obtained from the linear Fineman-Ross plot show both $\mathrm{r}_{1}\left(k_{\mathrm{EE}} / k_{\mathrm{EN}}\right)$ and $\mathrm{r}_{2}\left(k_{\mathrm{NN}} / k_{\mathrm{NE}}\right)$ are smaller than 1, revealing that both EE- and NN-insertion would be more difficult than EN- or NE-insertion [80]. Synthesis of the alternating copolymer is important for optical applications, since the chemical homogeneous products generate high transparency. The more the percentage compositions of alternating microstructures the copolymers contain, the higher the chemical homogeneity [73].

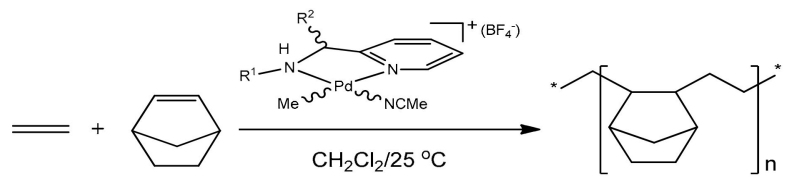

Scheme 1. Alternating E-N Copolymerization reactions, catalyzed by $\{[(\alpha$-Amino-pyridine $)] \mathrm{Pd}(\mathrm{Me})(\mathrm{NCMe})]\}\left[\mathrm{BF}_{4}\right]$.

In order to obtain more detailed information on the structure-reactivity relationship for COC formation (in terms of the late transition metal complexe $\{[(\alpha$-Amino-pyridine $\left.)] \mathrm{Pd}(\mathrm{Me})(\mathrm{NCMe})]\}\left[\mathrm{BF}_{4}\right]\right)$, we carefully examined the kinetics in many catalysis-related fundamental steps. Considering E-N copolymerization may be initiated from olefin-coordination, methylpalladium (1) and norbornylpalladium (2) complexes were chosen to study both norbornene and ethylene insertion, as well as their geometric isomerization. The kinetics provide the $\mathrm{E}-\mathrm{N}$ copolymerization rate constants $k_{\mathrm{EN}}, k_{\mathrm{EE}}, k_{\mathrm{NN}}$, whilst $k_{\mathrm{NE}}$ was given by DFT calculations. The mechanism and the complete energy profiles for the organopalladium catalyzed alternating COC formation were also evaluated. The results establish a comprehensive mechanistic picture that may account for the alternating COC microstructures, caused by the $\{[(\alpha-$ Amino-pyridine $)] \operatorname{Pd}(\mathrm{Me})(\mathrm{NCMe})]\}\left[\mathrm{BF}_{4}\right]$ system.

\section{Results and Discussion}

\subsection{Synthesis and Characterization of Norbornyl Palladium Complexes}

The norbornylpalladium complexes $\left\{\left[\mathrm{RHNCH}_{2}\left(o-\mathrm{C}_{6} \mathrm{H}_{4} \mathrm{~N}\right)\right] \mathrm{Pd}\left(\mathrm{C}_{7} \mathrm{H}_{10} \mathrm{Me}\right)(\mathrm{NCMe})\right\}\left(\mathrm{BF}_{4}\right)(\mathrm{R}=$ $\left.{ }^{i} \operatorname{Pr}(\mathbf{2 a}),{ }^{t} \mathrm{Bu}(\mathbf{2 b}), \mathrm{Ph}(\mathbf{2 c}), 2,6-\mathrm{Me}_{2} \mathrm{C}_{6} \mathrm{H}_{3}(\mathbf{2 d}), 2,6-{ }^{i} \mathrm{Pr}_{2} \mathrm{C}_{6} \mathrm{H}_{3}(\mathbf{2 e})\right)$ were synthesized from the reaction of the corresponding methylpalladium complexes $1 \mathbf{a}-\mathbf{e}$ and 1.3 molar equivalents of norbornene, to achieve satisfactory yields in MeCN/THF $(v / v=1 / 8)$ (Scheme 2). The weakly donating solvents could efficiently suppress successive norbornene-insertion [81].

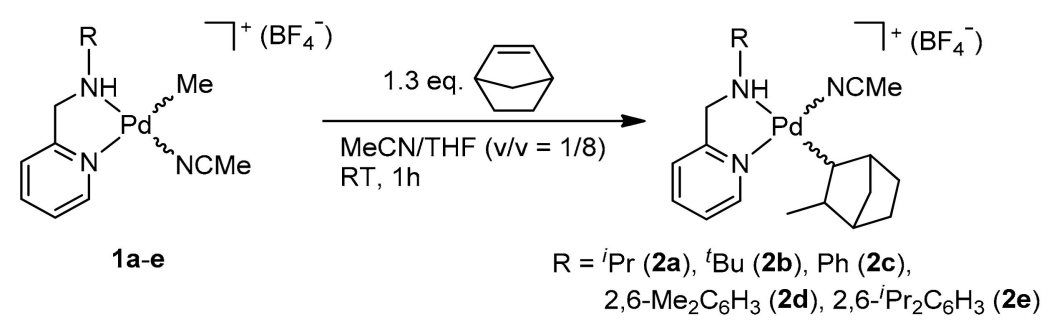

Scheme 2. Synthesis of Norbornylpalladium Complexes.

Notably, the norbornylpalladium complexes, synthesized via single $\mathrm{N}$-insertion into a catalytically active species, in a process of polyolefin formation, are rare [81]. Only a few examples had been achieved either by introducing a functionalized alkyl on the olefin [82-88], or through a neutral palladium species that showed relatively lower affinity to the olefins [89-91]. The NMR data measured in $\mathrm{CDCl}_{3}$ show that two diastereomers, exclusively in trans-diastereomers ( $T$-form), are identified 
for $\mathbf{2} \mathbf{a}-\mathbf{b}$, according to the NOE cross-peaks between the norbornyl and ortho-H of pyridine in the NOESY spectra. However, in the cases of $\mathbf{2} \mathbf{c}-\mathbf{e}$, the cis-diastereomers ( $C$-form) in low yields are also detected, as listed in Table 1. Herein, T-geometrical isomers are designated according to the trans-disposition between pyridine and $\mathrm{MeCN}$ (vide infra); and, the C-form for such ligands that are in the cis configuration (Figure 1). The selectivity of $T$-form in $\mathbf{2} \mathbf{a}, \mathbf{b}$ is ascribed to the steric hindrance between the amino substituent and the bulky norbornyl group. Such a factor turns out to be critical to the kinetic and thermodynamic selectivity (vide infra). The formation of small amounts of the $C$-form in $\mathbf{2 c - e}$ is allowed, presumably due to the constraint of free rotation (due to the amino aryl substituents).

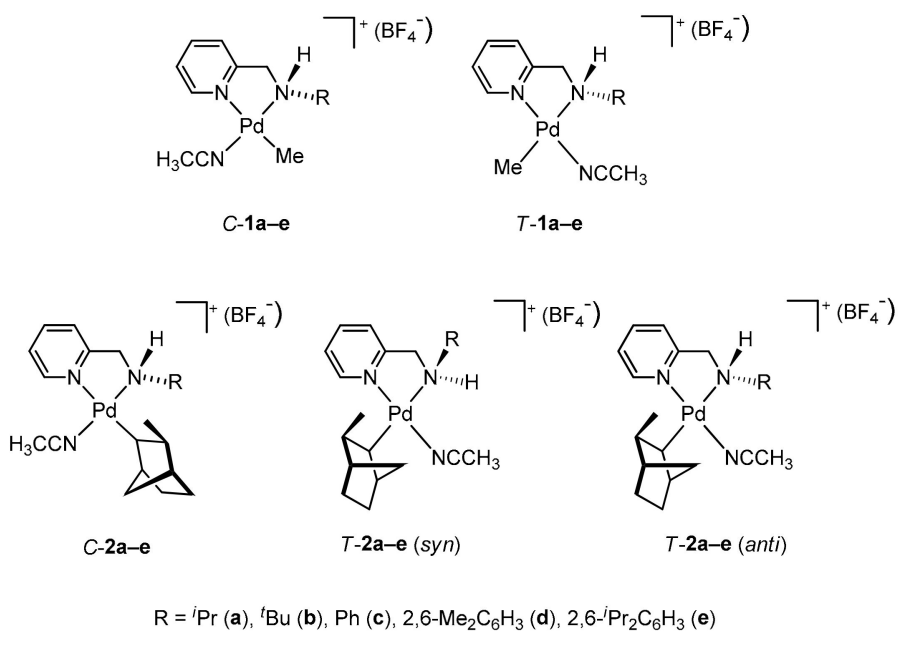

Figure 1. Isomers of complexes $1 \mathbf{a}-\mathbf{e}$ and $\mathbf{2 a}-\mathbf{e}$.

Table 1. Relative abundance for the isomers of $\mathbf{1}$ and 2.

\begin{tabular}{|c|c|c|c|c|c|c|}
\hline $\mathrm{RHNCH}_{2}\left(o-\mathrm{C}_{6} \mathrm{H}_{4} \mathrm{~N}\right)$ & & Me-Pd [8 & & & $\mathrm{MeC}_{7} \mathrm{H}_{10}-\mathrm{Pd}$ & \\
\hline $\mathbf{R}$ & & $T(\%)$ & $C(\%)$ & & $T(\%)(a n t i / s y n)$ & $C(\%)$ \\
\hline${ }^{i} \operatorname{Pr}$ & 1a & 82 & 18 & $2 \mathbf{a}$ & $100(30 / 70)$ & 0 \\
\hline${ }^{t} \mathrm{Bu}$ & $1 b$ & 100 & 0 & $2 b$ & $100(27 / 73)$ & 0 \\
\hline $\mathrm{Ph}$ & 1c & 93 & 7 & $2 c$ & $96(41 / 55)$ & 4 \\
\hline $2,6-\mathrm{Me}_{2} \mathrm{C}_{6} \mathrm{H}_{3}$ & 1d & 60 & 40 & $2 d$ & $87(47 / 40)$ & 13 \\
\hline $2,6-{ }^{i} \mathrm{Pr}_{2} \mathrm{C}_{6} \mathrm{H}_{3}$ & 1e & 62 & 38 & $2 e$ & $94(44 / 50)$ & 6 \\
\hline
\end{tabular}

The major diastereomer for $\mathbf{2} \mathbf{a}, \mathbf{b}$ is in syn-configuration, in which the methyl on norbornyl and the amino substituent are at the same side, with respect to the coordination plane (Figure 1). The NOESY spectra also show the NOE cross-peaks between these two alkyl groups. The pyridinyl $o$-H signal of anti-configuration for $\mathbf{2} \mathbf{a}, \mathbf{b}$ is found more downfield than in the syn-configuration (2a: anti/syn= 8.42/8.32 ppm; $\mathbf{2 b}$ : anti/syn $=8.39 / 8.29 \mathrm{ppm})$. Accordingly, the relative yields of syn/anti-products for $\mathbf{2 c - 2 e}$ are evaluated.

The crystallographic analyses provide unequivocal evidence for the molecular structures of these geometrical isomers. The single crystals of $T-2 b$ and $C-2 e$ were grown from co-solvents of $\mathrm{Et}_{2} \mathrm{O} / \mathrm{MeCN} / \mathrm{CH}_{2} \mathrm{Cl}_{2}$, and their ORTEP drawings are depicted in Figure 2. The collection of C-2e, which is of the kinetic product from $\mathrm{N}$-insertion into 1e, is probably due to ready decomposition of the thermodynamically stable $T-2 \mathbf{e}$, via C-H activation at ${ }^{i} \operatorname{Pr}_{2} \mathrm{C}_{6} \mathrm{H}_{3}$ [92,93]. The bond lengths of $\mathrm{Pd}-\mathrm{N} 1\left(\mathrm{sp}^{2}\right), \mathrm{Pd}-\mathrm{N} 2\left(\mathrm{sp}^{3}\right)$, and Pd-N3(sp) of $\mathbf{2} \mathbf{b}, \mathbf{e}$ are comparable with the data of 1a-e [80]. All structural parameters collected in Table S1 are in agreement with the literature data [89-91]. 


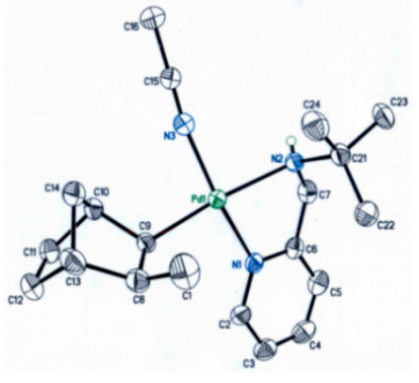

(A)

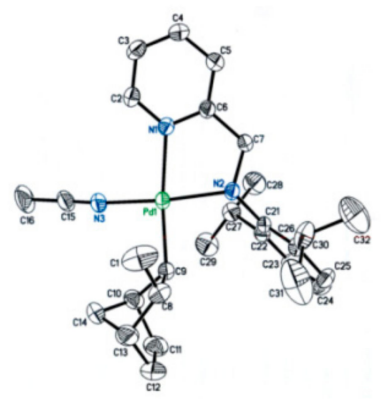

(B)

Figure 2. ORTEP drawings of (A) $\left\{\left[{ }^{t} \mathrm{BuHNCH}_{2}\left(o-\mathrm{C}_{6} \mathrm{H}_{4} \mathrm{~N}\right)\right] \mathrm{Pd}\left[\left(\mathrm{C}_{7} \mathrm{H}_{10}\right) \mathrm{Me}\right](\mathrm{NCMe})\right\}\left(\mathrm{BF}_{4}\right)(T-2 \mathbf{b})$; (B) $\left\{\left[\left(2,6-{ }^{i} \mathrm{Pr}_{2} \mathrm{C}_{6} \mathrm{H}_{3}\right) \mathrm{HNCH}_{2}\left(o-\mathrm{C}_{6} \mathrm{H}_{4} \mathrm{~N}\right)\right] \mathrm{Pd}\left[\left(\mathrm{C}_{7} \mathrm{H}_{10}\right) \mathrm{Me}\right](\mathrm{NCMe})\right\}\left(\mathrm{BF}_{4}\right)(\mathrm{C}-2 \mathbf{e})$; all H-atoms are omitted for clarity.

\subsection{Geometrical Isomerisation of Norbornylpalladium Complex}

Dissolving the crystal of $C-2 \mathbf{e}$ in $\mathrm{CDCl}_{3}$ in ambient conditions resulted in transformation into T-2e, with the $\mathrm{T} / \mathrm{C}$ ratio of $94 / 6$. The equilibrium constant $\left(\mathrm{K}_{\mathrm{eq}}\right)$ is estimated as 15.7 (T over $C$ ). The value of $\Delta \mathrm{G}^{0}$ at $298 \mathrm{~K}$ is thus $-1.6 \mathrm{kcal} / \mathrm{mol}$, calculated from $\mathrm{K}_{\mathrm{eq}}$. The time-resolved spectra of such an isomerization reaction were monitored by variable-temperature ${ }^{1} \mathrm{H}-\mathrm{NMR}$ technique. The changes of pyridine $(o-\mathrm{H}), \mathrm{NH}$, and the norbornyl endo- $\mathrm{CH}_{2}$ signals show the formation of two diastereomers (Figure 3). The chemical shifts for the endo- $\mathrm{CH}_{2}$ of the norbornyl group in $\mathrm{C}-2 \mathbf{e}$ are much more upfield than in T-2e, presumably caused by the ring current from the amino aryl. Kinetic analysis showed that this isomerization reaction gives first-order rate constants $5.48 \times 10^{-5}-5.69 \times 10^{-3} \mathrm{~s}^{-1}$, at $248-273 \mathrm{~K}$. The differences of activation enthalpy $\left(\Delta \mathrm{H}^{\ddagger}\right.$ isom $)$, Gibbs energy $\left(\Delta \mathrm{G}^{\ddagger}\right.$ isom $)$, and entropy $\left(\Delta \mathrm{S}^{\ddagger}{ }_{\text {isom }}\right)$, derived from the linear Eyring relationship, are $21.5 \mathrm{kcal} / \mathrm{mol}, 18.7 \mathrm{kcal} / \mathrm{mol}$, and $9.5 \mathrm{cal} / \mathrm{mol} \cdot \mathrm{K}$, respectively (Figure S5).

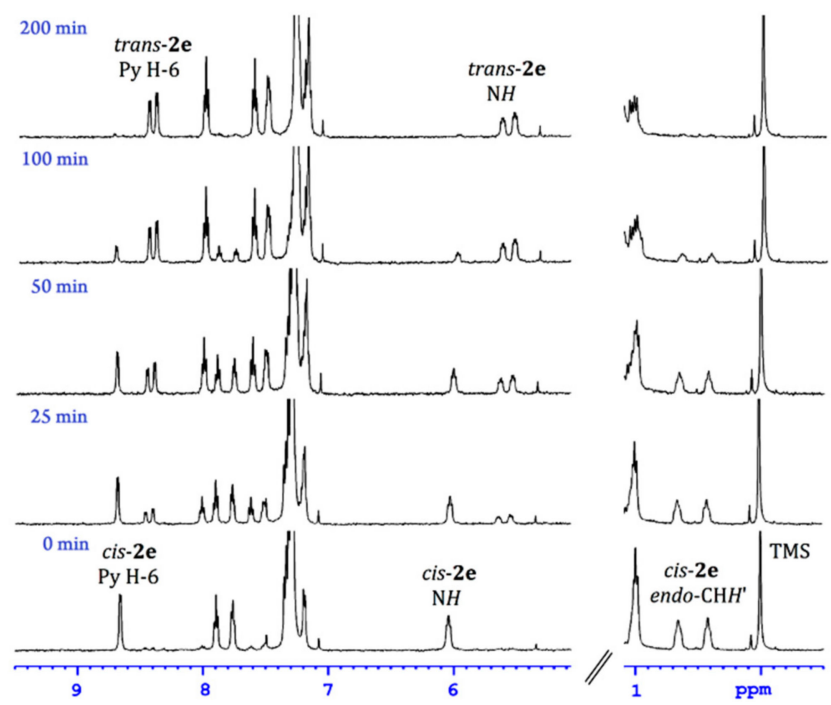

Figure 3. Time-resolved ${ }^{1} \mathrm{H}-\mathrm{NMR}$ spectra for geometrical isomerization of $\mathrm{C}-\mathbf{2} \mathbf{e}$ to $T-\mathbf{2 e}$, at $253 \mathrm{~K}$ in $\mathrm{CDCl}_{3}$.

The small positive value of $\Delta S_{\text {isom }}^{\ddagger}$ suggests that the geometrical isomerization of 2e may undergo intramolecular amine decoordination-recoordination, along with amine inversion, leading to enantioisomeric exchange (Scheme 3) (although the solvent-assisted associative pathway may also be possible) [94]. The steric repulsion between the amino substituent and the norbornyl group significantly destabilizes the ground state of $\mathbf{C - 2 e}$, and drives the amine group dissociation. Such a 
mechanism is also supported by the diastereotopic H-exchange of backbone methylene, in prior work of similar derivatives [90].

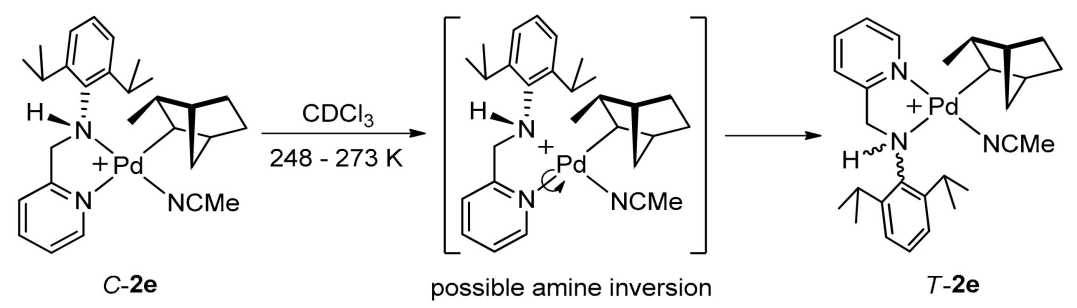

Scheme 3. Isomerization reaction mechanism of C-2e.

\subsection{Kinetics of Norbornene Insertion Reactions in Organopalladium(II) Complexes}

Treatment of 1a-e with excess norbornene gave rise to the formation of polyads of norbornyl units, via successive norbornene insertions. To our surprise, all products are in $T$-form, as displayed in Scheme 4. Besides, the product of tetra-ads $(n=3)$ was absent upon the reaction course. If the reactions were carried out at $228-263{ }^{\circ} \mathrm{C}$, the products $\mathbf{2 a}-\mathbf{e}$ were respectively produced first, and the multi- $N$-inserted products $\mathbf{3 a}-\mathbf{e}(n=1)$, such as diads and triads $\mathbf{3} \mathbf{a}^{\prime}-\mathbf{e}^{\prime}(n=2)$, were ensuing. In addition, the norbornene-coordinated species and free $\mathrm{MeCN}$ were not observed, indicating that the norbornene coordination, instead of migratory insertion, may be rate-determining (Scheme 4). The fact suggests that this case is very different from the reactions of alternating E-N copolymerization, catalyzed by bis(pyrrolide-imine)titanium, in which the olefin-insertion steps are rate-determining [23].

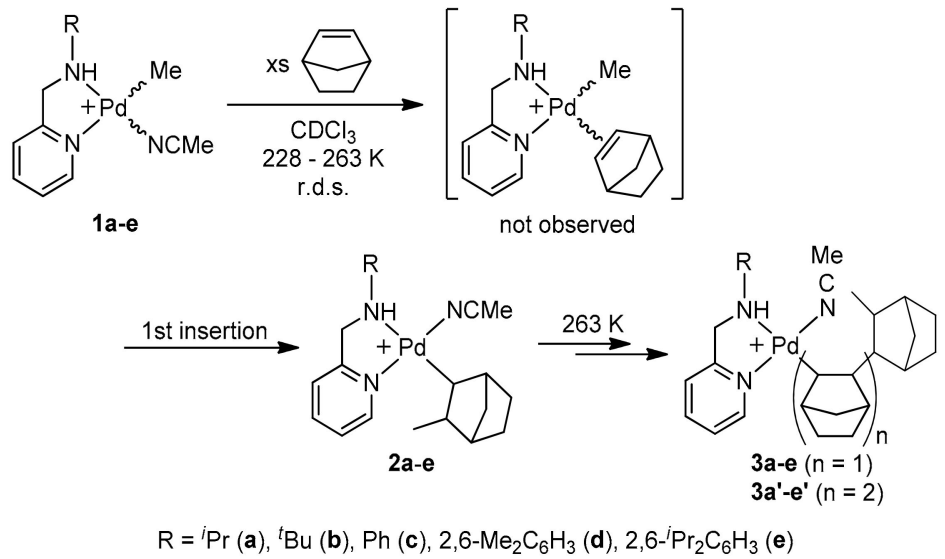

Scheme 4. Reactions of successive N-Insertion in 1a-e.

The kinetic studies on the reactions of the first $\mathrm{N}$-insertion for $\mathbf{1 a}-\mathbf{e}$ were further examined with use of ${ }^{1} \mathrm{H}$ VT-NMR in a pseudo-first-order manner. As listed in Table 2, entries 1-5 show the effect of the amino substituents on the reactivity at $263 \mathrm{~K}$. In entries $1-3$, only the rate constants for the $T$-form $\left(k_{\mathrm{obs}}{ }^{T}\right)$ were evaluated, since the $C$-isomer was consumed under the conditions before the 1 st measurement. An attempt to record $k_{\mathrm{obs}}{ }^{c}$ in the condition of lower norbornene concentration failed, because the reaction would proceed too slowly to be monitored. Complex $\mathbf{1 b}$ is significantly slower toward norbornene insertion than the runs of other analogous complexes. The observation of the smaller $k_{\mathrm{obs}}{ }^{T}$ value of $\mathbf{1 b}$ is probably because of the bulky ${ }^{t} \mathrm{Bu}$ substituent on the amine group, which would hinder the norbornene coordination, and thus retard the norbornene-insertion rate.

It is worth noting that in entry 4 the $k_{\mathrm{obs}}{ }^{C}$ is 6.1 fold faster than $k_{\mathrm{obs}}{ }^{T}$. Similarly, the $k_{\mathrm{obs}}{ }^{C}$ are 46 and 32 folds of $k_{\text {obs }}{ }^{T}$ in entries 11 and 12, respectively. Moreover, if the reactions were carried out in temperatures lower than $243 \mathrm{~K}$ (entries 13-18), only the consumption of the C-isomer was observed. 
The facts indicate that in such low temperatures, no $T$-to- $C$ isomerization occurs, and the reaction of norbornene-insertion only takes place on the $C$-isomer. This is an unprecedented example, of which one geometrical isomer in square-planar configuration shows substantially more facile reactivity than another toward the fundamental reactions of norbornene insertion $[85,95]$.

To shed further light on the kinetics of the norbornene insertion, we chose 1e to determine the rate laws. The plots of the pseudo-first-order rate constants, against the concentration of norbornene ([N]) in Figure S24, show that $k_{\text {obs }}{ }^{C}$ is directly proportional to [N] (Entries 15-17), while $k_{\text {obs }}^{T}[\mathrm{~N}]$ relationship is linear with a non-zero intercept, which represents the rate constant of $T$-to- $C$ isomerization,

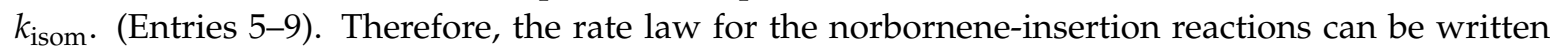
as Equations (1) and (2), indicating that in $\mathrm{C}-\mathbf{1 e}$ the rate of $\mathrm{N}$-insertion is much faster than that of isomerization (whereas in $T-\mathbf{1 e}$, the two reactions compete with each other).

$$
\begin{gathered}
-\frac{\mathrm{d}[C-\mathbf{1 e}]}{\mathrm{dt}}=k_{\mathrm{obs}}^{\mathrm{C}-1 \mathbf{e}}[C-\mathbf{1 e}]=k_{\mathrm{N}}^{\mathrm{C}-\mathbf{1 e}}[\mathrm{N}][C-\mathbf{1 e}] \\
-\frac{\mathrm{d}[T-\mathbf{1 e}]}{\mathrm{dt}}=k_{\mathrm{obs}}^{T-\mathbf{1 e}}[T-\mathbf{1 e}]=\left(k_{\mathrm{N}}^{C-1 \mathbf{e}}[\mathrm{N}]+k_{\text {isom }}\right)[T-\mathbf{1 e}]
\end{gathered}
$$

Indeed, the rate constants $k_{\mathrm{N}}{ }^{\mathrm{C}-1 \mathbf{e}}\left(\right.$ Entry 10) and $k_{\mathrm{N}}^{T-1 \mathbf{e}}$ at $263 \mathrm{~K}$ were evaluated as $3.06 \times 10^{-1}$ and $2.14 \times 10^{-3} \mathrm{M}^{-1} \mathrm{~s}^{-1}$, and the rate constants of $T$-to- $C$ and $C$-to- $T$ isomerization $\left(k_{\text {isom }}\right.$ and $\left.k_{\text {isom }}{ }^{-1}\right)$ were estimated as $4.60 \times 10^{-4}$ and $8.48 \times 10^{-4} \mathrm{~s}^{-1}$ (Data were obtained from the intercept of the $k_{\mathrm{obs}}{ }^{T}$-[N] linear and the equilibrium constant of isomerization $\left(\mathrm{K}_{\mathrm{C} / \mathrm{T}}=0.54\right.$ at $\left.263 \mathrm{~K}\right)$ ). Furthermore, $\Delta \mathrm{H}^{\ddagger} \mathrm{N}$ and $\Delta S^{\ddagger}{ }_{N}$ for the $\mathrm{N}$-insertion reaction of $C$-1e were obtained from the Eyring plot, as $13.8 \mathrm{kcal} / \mathrm{mol}$ and $-8.9 \mathrm{cal} / \mathrm{mol} \cdot \mathrm{K}$, respectively (entries 11-14 and 18, Figure S25). The small negative value of $\Delta S^{\ddagger} \mathrm{N}$ agrees with an intermediate A-pathway [96]. One may assert that the rate-determining step of norbornene-coordination tends to be critically dependent on the steric hindrance between the amino substituent and the norbornene. Such a stress may be released via either geometrical isomerization or migratory $\mathrm{N}$-insertion.

Table 2. Kinetic data for norbornene insertion reactions of $\left\{\left[\mathrm{RHNCH}_{2}\left(o-\mathrm{C}_{6} \mathrm{H}_{4} \mathrm{~N}\right)\right] \mathrm{Pd}(\mathrm{Me})\right.$ $(\mathrm{NCMe})\}\left(\mathrm{BF}_{4}\right)\left(\mathrm{R}={ }^{i} \mathrm{Pr}(\mathbf{1 a}),{ }^{t} \mathrm{Bu}(\mathbf{1 b}), \mathrm{Ph}(\mathbf{1} \mathbf{c}), 2,6-\mathrm{Me}_{2} \mathrm{C}_{6} \mathrm{H}_{3}(\mathbf{1 d}), 2,6-{ }^{i} \mathrm{Pr}_{2} \mathrm{C}_{6} \mathrm{H}_{3}(\mathbf{1 e})\right)$ in $\mathrm{CDCl}_{3}$.

\begin{tabular}{ccccccc}
\hline \multirow{2}{*}{ Entry } & Cat & Temp. (K) & {$[\mathbf{C a t}]\left(\times \mathbf{1 0}^{-\mathbf{3}} \mathbf{M}\right)$} & {$[\mathbf{N}]{ }^{\mathbf{a}} /[\mathbf{C a t}]$} & \multicolumn{2}{c}{$\boldsymbol{k}_{\mathbf{o b s}}\left(\mathbf{1 0 ^ { - 4 }} \mathbf{s}^{\mathbf{- 1}}\right)$} \\
\hline 1 & $\mathbf{1 a}$ & 263 & 5.3 & 28.7 & $-\mathrm{b}$ & 8.69 \\
2 & $\mathbf{1 b}$ & 263 & 24.9 & 82.2 & $-\mathrm{c}$ & 2.40 \\
3 & $\mathbf{1 c}$ & 263 & 2.0 & 23.2 & $-\mathrm{b}$ & 51.60 \\
4 & $\mathbf{1 d}$ & 263 & 1.1 & 16.7 & 134.00 & 21.80 \\
5 & $\mathbf{1 e}$ & 263 & 3.4 & 10.8 & $-\mathrm{b}$ & 5.47 \\
6 & $\mathbf{1 e}$ & 263 & 3.4 & 24.2 & $-\mathrm{b}$ & 6.19 \\
7 & $\mathbf{1 e}$ & 263 & 3.4 & 62.6 & $-\mathrm{b}$ & 10.10 \\
8 & $\mathbf{1 e}$ & 263 & 3.4 & 134.5 & $-\mathrm{b}$ & 12.90 \\
9 & $\mathbf{1 e}$ & 263 & 3.4 & 260.9 & $-\mathrm{b}$ & 23.80 \\
10 & $\mathbf{1 e}$ & 263 & 1.7 & 21.0 & 110.00 & - \\
11 & $\mathbf{1 e}$ & 258 & 3.3 & 31.1 & 109.00 & 2.35 \\
12 & $\mathbf{1 e}$ & 253 & 3.4 & 26.3 & 41.30 & 1.29 \\
13 & $\mathbf{1 e}$ & 243 & 3.3 & 28.0 & 16.80 & - \\
14 & $\mathbf{1 e}$ & 238 & 3.4 & 27.2 & 9.68 & - \\
15 & $\mathbf{1 e}$ & 233 & 3.3 & 20.1 & 7.11 & - \\
16 & $\mathbf{1 e}$ & 233 & 3.3 & 33.7 & 10.80 & - \\
17 & $\mathbf{1 e}$ & 233 & 3.3 & 40.5 & 12.90 & - \\
18 & $\mathbf{1 e}$ & 228 & 3.4 & 31.3 & 2.50 & - \\
\hline
\end{tabular}

a Determined by ${ }^{1} \mathrm{H}-\mathrm{NMR}$, using tetramethylsilane as an internal standard; ${ }^{\mathrm{b}}$ the $\mathrm{C}$-isomer was consumed under the conditions before the 1 st measurement; ${ }^{c}$ no $C$-isomer. 
If the $\mathrm{N}$-insertion is much more favored in the $\mathrm{C}$-form, the problem then arises: why were no PN products observed? A reasonable assumption is that the steric hindrance would be increased by the increasing numbers of inserted norbornene, inhibiting the coordination step. Accordingly, we investigated the 2 nd and the 3 rd insertion rates for $1 \mathbf{a}$ at $263 \mathrm{~K}$, and found they are ranked in the order of 1 st $>2$ nd $\sim 3$ rd $>>4$ th (Figure S26 and Table S9).

The norbornene-insertion reactions of $\mathbf{1}$ and $\mathbf{2}$ are worthy to note in several aspects: (1) the $\mathrm{N}$-coordination step is rate-determining, and the $\mathrm{N}$-insertion reactions are favored in the cis isomers; (2) the products favor the trans isomers, and the $C-T$ isomerizations take place owing to the steric effects in the hemilabile ligands; and (3) the geometrical isomerization is capable of winning the competition over the successive $\mathrm{N}$-insertion, thus facilitating the alternating $\mathrm{N}-\mathrm{E}$-insertion.

\subsection{Kinetics of Ethylene Insertion Reactions in Organopalladium(II) Complexes}

In the presence of excess ethylene, $\mathrm{MeCN}$ in $\mathbf{1 a}-\mathbf{e}$ were readily replaced by ethylene to form $T / C-\left\{\left[\operatorname{RHNCH}_{2}\left(o-\mathrm{C}_{6} \mathrm{H}_{4} \mathrm{~N}\right)\right] \mathrm{Pd}(\mathrm{Me})\left(\mathrm{C}_{2} \mathrm{H}_{4}\right)\right\}\left(\mathrm{BF}_{4}\right)\left(\mathbf{1 a}^{\prime}-\mathbf{e}^{\prime}\right)$, followed by the E-insertion and an ensuing E-coordination to give $T / C$ - $\left.\left\{\left[\mathrm{RHNCH}_{2}\left(o-\mathrm{C}_{6} \mathrm{H}_{4} \mathrm{~N}\right)\right] \mathrm{Pd}\left(\mathrm{C}_{3} \mathrm{H}_{7}\right)\left(\mathrm{C}_{2} \mathrm{H}_{4}\right)\right\} \mathrm{BF}_{4}\right)\left(4 \mathbf{a}^{\prime}-\mathbf{e}^{\prime}\right)$, as shown in Scheme 5.

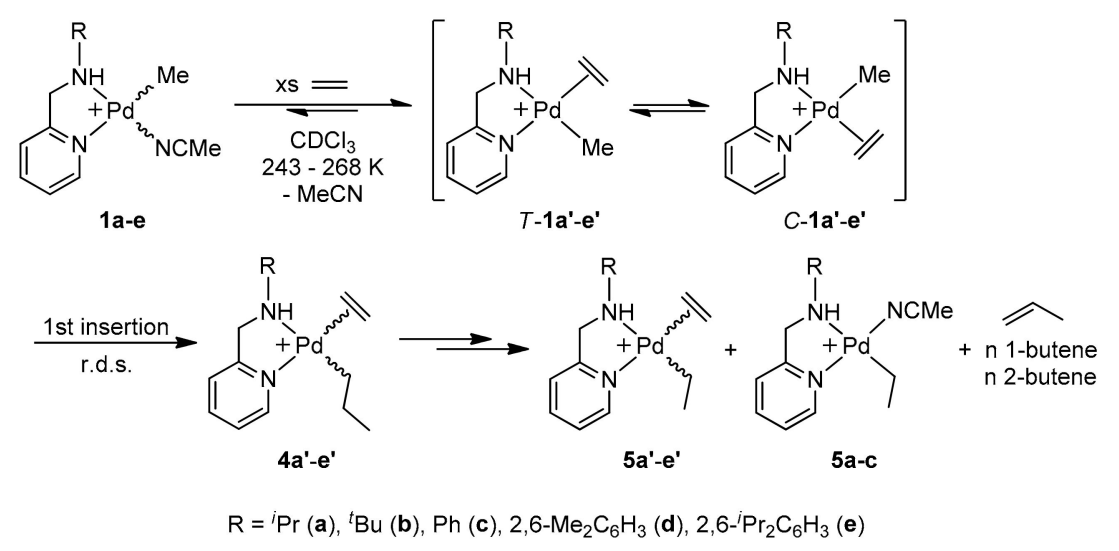

Scheme 5. E-Insertion Reactions in complexes 1a-e.

Consequently, ethyl(ethylene)palladium in the form of $T / C-\left\{\left[R H N C H_{2}\left(o-C_{6} \mathrm{H}_{4} \mathrm{~N}\right)\right] \mathrm{Pd}(\mathrm{Et})\left(\mathrm{C}_{2} \mathrm{H}_{4}\right)\right\}-$ $\left(\mathrm{BF}_{4}\right)\left(5 \mathbf{a}^{\prime}-\mathbf{e}^{\prime}\right)$, along with the propene and butenes of chain-transfer products, were detected [97]. $T-\left\{\left[\mathrm{RHNCH}_{2}\left(o-\mathrm{C}_{6} \mathrm{H}_{4} \mathrm{~N}\right)\right] \mathrm{Pd}(\mathrm{Et})(\mathrm{MeCN})\right\}\left(\mathrm{BF}_{4}\right)(5 \mathrm{a}-\mathrm{c})$, with respective yields of $29 \%, 50 \%$, and $24 \%$, were also obtained. The absence of the $\mathbf{C}-\mathbf{5 a}-\mathbf{c}$ is presumably due to the conformational steric hindrance between the amino substituent and the ethyl ligand [80,98]. T-forms are of the more favored configurations in $\mathbf{1} \mathbf{a}^{\prime}-\mathbf{d}^{\prime}$ and $\mathbf{5} \mathbf{a}^{\prime}-\mathbf{e}^{\prime}$, again, ascribed to the steric effect (Table 3). The E-coordinated complexes appear to undergo geometrical isomerization more facile than that in $\mathbf{2 a}-\mathbf{e}$, according to the broadened or coalescent Pd-alkyl signals for $\mathbf{1} \mathbf{b}^{\prime}-\mathbf{e}^{\prime}, \mathbf{5} \mathbf{a}^{\prime}-\mathbf{b}^{\prime}$, and $\mathbf{5} \mathbf{d}^{\prime}-\mathbf{e}^{\prime}$ found at $263 \mathrm{~K}$.

Table 3. The yields of E-coordinated Pd(II) species, from the reactions of 1 and ethylene in $\mathrm{CDCl}_{3}$.

\begin{tabular}{|c|c|c|c|c|c|c|}
\hline \multirow{2}{*}{\multicolumn{2}{|c|}{$\frac{\mathrm{RHNCH}_{2}\left(o-\mathrm{C}_{6} \mathrm{H}_{4} \mathrm{~N}\right)}{\mathrm{R}}$}} & \multicolumn{4}{|c|}{ E-Coord. Complexes } & \multirow[b]{2}{*}{$C(\%)$} \\
\hline & & $T(\%)$ & $C(\%)$ & & $T(\%)$ & \\
\hline${ }^{i} \operatorname{Pr}$ & $1 a^{\prime}$ & 58 & 42 & $5 a^{\prime}$ & 59 & 41 \\
\hline${ }^{t} \mathrm{Bu}$ & $1 b^{\prime}$ & 63 & 37 & $5 b^{\prime}$ & 58 & 42 \\
\hline $\mathrm{Ph}$ & $1 c^{\prime}$ & 100 & 0 & $5 c^{\prime}$ & 100 & 0 \\
\hline $2,6-\mathrm{Me}_{2} \mathrm{C}_{6} \mathrm{H}_{3}$ & $1 d^{\prime}$ & 59 & 41 & $5 d^{\prime}$ & 64 & 36 \\
\hline $2,6-{ }^{i} \operatorname{Pr}_{2} \mathrm{C}_{6} \mathrm{H}_{3}$ & $1 e^{\prime}$ & 38 & 62 & $5 e^{\prime}$ & 67 & 33 \\
\hline
\end{tabular}


The kinetic data in Table 4 were collected by monitoring the Me-Pd signals of 1a-e under pseudo-first-order conditions, with excess of [E]. The values of $k_{\mathrm{E}}$ were measured from the transformations of $\mathbf{1} \mathbf{a}^{\prime}-\mathbf{e}^{\prime}$ to $4 \mathbf{a}^{\prime}-\mathbf{e}^{\prime}$. Unlike in the processes of N-insertion, the migratory E-insertion in $\mathbf{1}^{\prime}$ is comparable between two geometrical isomers. On the other hand, the differences of $k_{\mathrm{E}}$ are limited in terms of ligand variation (Entries 1-4 and 6).

In entries 6-8, the values of $k_{\mathrm{E}}$ for $1 \mathrm{e}$ appear to be independent on [E], suggesting the rate-determining step ought to be the step of E-insertion [93,99-102]. Moreover, the Eyring analyses provide the activation parameters of the E-insertion in $1 \mathbf{e}$, as $17.3 \mathrm{kcal} / \mathrm{mol}$ for $\Delta \mathrm{H}^{\ddagger} \mathrm{E}$ and $-7.4 \mathrm{cal} / \mathrm{mol} \cdot \mathrm{K}$ for $\Delta \mathrm{S}^{\ddagger} \mathrm{E}$, that are comparable to those for $\mathrm{N}$-insertion in $\mathrm{C}$-1e. That is probably also an accidental factor for the occurrence of the $\mathrm{E}-\mathrm{N}$ alternating copolymerization.

In summary for the E-insertion reactions of 1a-e, the E-coordination to 1, as well as the geometrical isomerization of the ethylene-coordinated species, has to be ready. The successive E-insertions are quenched by $\beta$-elimination, but may be accelerated at high [E]. It is assumed that a hydridopalladium species may be formed by chain transfer, and serves as the actual catalytically active resting state. Overall, the E-insertions are less critical than the $\mathrm{N}$-insertions in $\left.\left\{\left[\mathrm{RHNCH}_{2}\left(o-\mathrm{C}_{6} \mathrm{H}_{4} \mathrm{~N}\right)\right] \mathrm{Pd}(\mathrm{Me})(\mathrm{NCMe})\right]\right\}\left[\mathrm{BF}_{4}\right]$ catalyzed formation of alternating COC.

Table 4. Kinetic data for the pseudo-first-order $k_{\mathrm{E}}$ of ethylene insertion reaction of $1 \mathrm{a}-\mathbf{e}$ in $\mathrm{CDCl}_{3}$.

\begin{tabular}{|c|c|c|c|c|c|c|c|}
\hline \multirow{2}{*}{ Entry } & \multirow{2}{*}{ Temp. (K) } & \multirow{2}{*}{ Cat } & \multirow{2}{*}{ [Cat] $\left(10^{-3} \mathrm{M}\right)$} & \multirow{2}{*}[E]{$^{a} /[$ Cat $]$} & \multicolumn{3}{|c|}{$k_{\mathrm{E}}\left(10^{-4} \mathrm{~s}^{-1}\right)$} \\
\hline & & & & & $C$ & $T$ & Total $^{b}$ \\
\hline 1 & 263 & $1 a$ & 5.3 & 18.3 & c & c & 6.44 \\
\hline 2 & 263 & $1 b$ & 3.6 & 21.3 & d & 8.05 & - \\
\hline 3 & 263 & 1c & 4.4 & 25.9 & e & 1.93 & - \\
\hline 4 & 263 & $1 d$ & 3.2 & 17.7 & 4.74 & 4.72 & 4.28 \\
\hline 5 & 268 & $1 e$ & 3.4 & 21.7 & 13.10 & 14.30 & 13.60 \\
\hline 6 & 263 & $1 e$ & 3.3 & 14.3 & 4.36 & 3.80 & 4.14 \\
\hline 7 & 263 & $1 e$ & 3.3 & 25.0 & 4.46 & 4.19 & 4.37 \\
\hline 8 & 263 & $1 e$ & 3.3 & 51.9 & 4.91 & 4.27 & 4.71 \\
\hline 9 & 258 & $1 e$ & 3.4 & 49.4 & 3.40 & 3.20 & 3.37 \\
\hline 10 & 253 & $1 e$ & 3.4 & 32.5 & 1.16 & 1.17 & 1.16 \\
\hline 11 & 243 & $1 e$ & 3.3 & 27.2 & 0.41 & 0.41 & 0.41 \\
\hline
\end{tabular}

a Determined by ${ }^{1} \mathrm{H}-\mathrm{NMR}$ spectra using tetramethylsilane as an internal standard; ${ }^{\mathrm{b}}$ the rate is estimated from the sum of decrease in intensity of $C$ - and $T$ - isomers in ${ }^{1} \mathrm{H}$-NMR spectra; ${ }^{c}$ the signals of $\mathrm{Pd}$-Me for $C$ - and $T$ - isomers are overlapped; ${ }^{\mathrm{d}}$ all the signals are overlapped; and ${ }^{\mathrm{e}}$ lack of $\mathrm{C}$ - isomer.

\subsection{DFT Approach for E-N Copolymerization}

Kinetic studies for $\mathrm{N}$-insertion and E-insertion reactions provide the evaluations of $k_{\mathrm{N}}$ and $k_{\mathrm{E}}$, respectively, which can model the $k_{\mathrm{EN}}, k_{\mathrm{NN}}$, and $k_{\mathrm{EE}}$ for E-N copolymerization. Nevertheless, the ${ }^{1} \mathrm{H}-\mathrm{NMR}$ spectra for the E-insertion reactions of $\mathbf{2 a -}-\mathbf{e}$ are too complicated to have successful kinetic analysis. In order to gain the missing information for $k_{\mathrm{NE}}$, and to have a comprehensive mechanistic picture for such alternating E-N copolymerization, the gas-phase DFT studies were applied (The chirality of amine is fixed as $R$ form not only for easier comparison but also due to the enantiomers giving almost the same energies in preliminary calculations. The energies for syn- and anti-isomers of norbornyl complex, showing similar energies, were also calculated from energy scan of rotating the $\mathrm{Pd}-\mathrm{C}$ bond on norbornyl ligand). The complex 1e was chosen for the calculations of the reaction energy profile, in which the fundamental steps were concerned. Considering the replacement of $\mathrm{E}$ for $\mathrm{MeCN}$ in organopalladium(II) complexes is feasible and complete (as shown in Scheme 5), the E-coordinated species $6 / \mathbf{6}^{\prime}$ and $8 / \mathbf{8}^{\prime}$, as illustrated in Chart 1 below, are proposed as the resting states for the calculations. 
<smiles></smiles>

$6(T)$

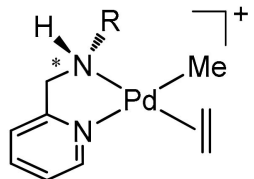

$6^{\prime}(C)$

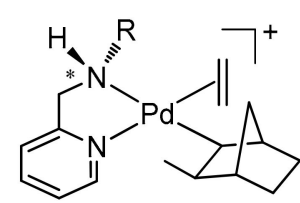

$\mathbf{8}(T)$

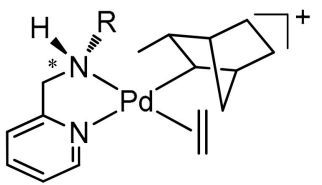

$8^{\prime}(C)$

Chart 1. Structures of resting states. $\left(\mathrm{R}=2,6-{ }^{i} \mathrm{Pr}_{2} \mathrm{C}_{6} \mathrm{H}_{3}\right)$.

\subsection{1. $C-T$ Isomerization}

As aforementioned, the isomerization reaction of $1 \mathbf{e}^{\prime}$ is more facile than those of $1 \mathbf{e}$ and $\mathbf{2 e}$, suggesting that the isomerizations with E-coordinate and $\mathrm{MeCN}$-coordinate organopalldium species might not be the same. We calculated several kinds of pathways such as A-type [103-105], D-type [106], amine-dissociation, Berry pseudorotation [107,108], and direct geometry change [109-113], and found that the last one is the most energy-favored. Rotation of the dihedral angle of $\mathrm{N}_{\mathrm{py}}-\mathrm{N}_{\mathrm{am}}-\mathrm{Pd}-\mathrm{C}_{\mathrm{Me}}$ affords pseudo penta-coordinate transition states TS(6-6') and TS $\left(6^{\prime}-6^{\prime}\right)^{\prime}$, with barriers of 14.0 and $18.1 \mathrm{kcal} / \mathrm{mol}$, respectively (Scheme 6). TS $\left(6-6^{\prime}\right)$ has a weak $\delta$-agostic interaction of the ${ }^{i} \operatorname{Pr}$ group, with the distance $\mathrm{Pd}-\mathrm{H}=2.5286 \AA$, shorter than the sum of Van der Waals radii ( $2.72 \AA)$.

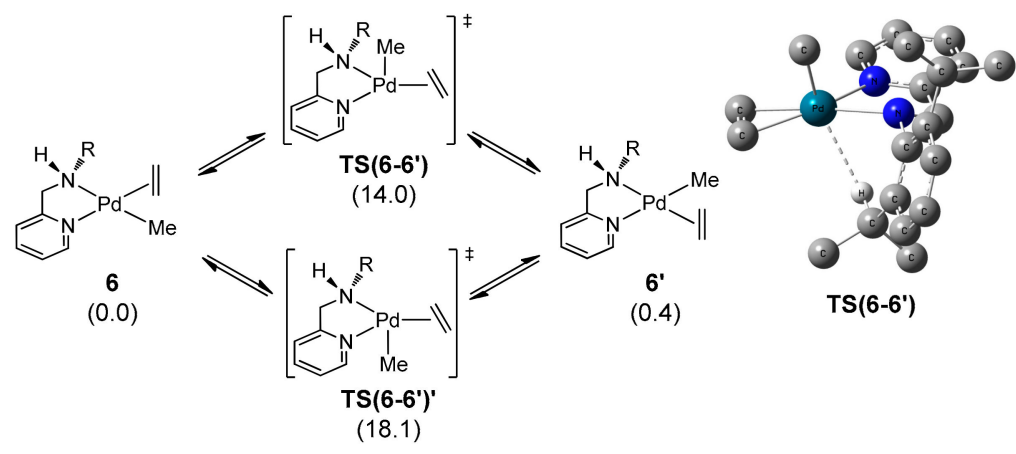

Scheme 6. $C-T$ isomerization via distorted tetrahedral species for norbornyl complexes $(E+Z P E$, $\mathrm{kcal} / \mathrm{mol})$. $\left(\mathrm{R}=2,6-{ }^{i} \mathrm{Pr}_{2} \mathrm{C}_{6} \mathrm{H}_{3}\right)$.

On the other hand, the amine decoordination-recoordination pathway has a barrier of $21.7 \mathrm{kcal} / \mathrm{mol}$, in agreement with the case of $2 \mathbf{e}$. The results show $C-T$ isomerization via pseudo penta-coordinate geometry is much lower in energy than via the amine-dissociation pathway. Accordingly, the isomerization mechanisms of the E-bound and MeCN-bond complexes are different. The former may undergo an unusual geometry change, and the later may likely go through amine dissociation. The difference successfully accounts for the experimental results that isomerization of E-bound species are more rapid than the $\mathrm{MeCN}$-bound ones. Likewise, the norboryl species 8 requires $15.1 \mathrm{kcal} / \mathrm{mol}$ to overcome activation energy to form $\mathbf{8}^{\prime}$, via a similar pathway of geometry change.

\subsubsection{Ethylene Insertion into $\left(\mathrm{C}_{2} \mathrm{H}_{4}\right) \mathrm{Pd}-\mathrm{Me}$}

The calculations for ethylene insertion reactions started from the E-bound methyl palladium species $\mathbf{6}$ and $\mathbf{6}^{\prime}$. As depicted in red in Figure 4, the endothermic insertion steps proceed with activation energies of 18.4 and $17.2 \mathrm{kcal} / \mathrm{mol}$, respectively, to give $\gamma$-agostic species $\mathbf{1 0}$ and $\mathbf{1 0}$ '. The former data is in excellent agreement with the kinetic data for $\mathbf{1 e}^{\mathbf{\prime}}(17.3 \mathrm{kcal} / \mathrm{mol})$. IRC scan led to local minima $\mathbf{6}$ and $\mathbf{6}^{\prime}$, and no in-plane $\pi$-complex could be found. The mechanism of ethylene insertion is also supported by the previous studies [93,99-102,114-116]. 


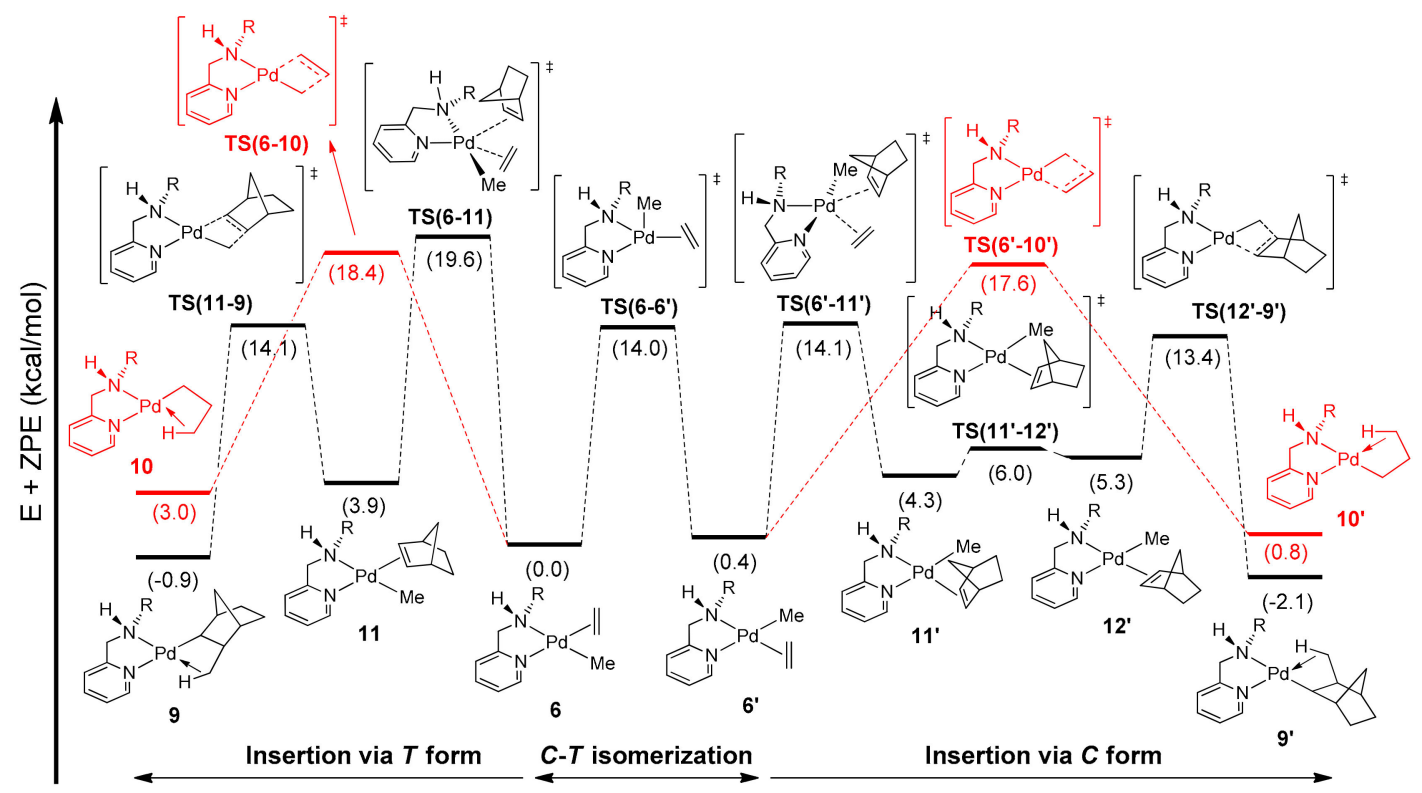

Figure 4. Energy profile for isomerization, ethylene, and norbornene propagation reaction of 6 and $\mathbf{6}^{\prime}$ $(\mathrm{E}+\mathrm{ZPE}, \mathrm{kcal} / \mathrm{mol}) \cdot\left(\mathrm{R}=2,6-{ }^{i} \mathrm{Pr}_{2} \mathrm{C}_{6} \mathrm{H}_{3}\right)$.

\subsubsection{Norbornene Insertion into $\left(\mathrm{C}_{2} \mathrm{H}_{4}\right) \mathrm{Pd}-\mathrm{Me}$.}

The norbornene insertion reactions of $\mathbf{6}$ and $\mathbf{6}^{\prime}$ start to approach Pd from the side, above the coordination plane of $6 / 6^{\prime}$. The transition states TS(6-11)/TS $\left(6^{\prime}-11^{\prime}\right)$ were found to be in the TBP structure. IRC calculations showed that TS(6-11) and TS $\left(6^{\prime}-\mathbf{1 1}^{\prime}\right)$ would respectively form the N-bound $\pi$-products $\mathbf{1 1}$ and 11', first by the olefin replacement. The activation barriers are 19.6 (via $T$-form) and 13.7 (via C-form) $\mathrm{kcal} / \mathrm{mol}$.

Although both substitution reactions are endothermic by $3.9 \mathrm{kcal} / \mathrm{mol}$, the conformation of norbornene in $\mathbf{1 1}$ and $\mathbf{1 1}^{\prime}$ are different. In $\mathbf{1 1}$, the bridge-head $\mathrm{CH}_{2}$ moiety tilts away from pyridine, while the $\mathrm{CH}_{2}$ directs toward the pyridine in $\mathbf{1 1}^{\prime}$. In consequence, insertion directly takes place from $\mathbf{1 1}$ to form the $\gamma$-agostic product 9 by $10.2 \mathrm{kcal} / \mathrm{mol}$ barrier. In contrast, $\mathbf{1 1}^{\prime}$ was turned to $\mathbf{1 2}$ ' by rotating norbornene, then norbornene insertion followed to give $\mathbf{9}^{\prime}$. The rotational motion and insertion barriers are calculated as 1.7 and $8.1 \mathrm{kcal} / \mathrm{mol}$, respectively. The reactions from $\mathbf{9}$ to $\mathbf{1 1}$ and $\mathbf{9}^{\prime}$ to $\mathbf{1 1}$ ' are thus exothermic by 4.8 and $7.4 \mathrm{kcal} / \mathrm{mol}$, respectively (Figure 4 ).

Overall, the rate-determining step of the norbornene insertions should be the substitution of ethylene by norbornene, via a transition state of $\mathrm{N}$-association $\left(\mathbf{T S}(\mathbf{6}-\mathbf{1 1}) / \mathrm{TS}\left(\mathbf{6}^{\prime}-\mathbf{1 1}^{\prime}\right)\right)$ from the E-bound species. The reaction via $C$-form requires a smaller energy barrier, and thus proceeds faster, consistent with the kinetic results of 1e. Again, the activation energy between $\mathbf{6}^{\prime}$ and TS(6'-11'), $14.1 \mathrm{kcal} / \mathrm{mol}$, meets the kinetic result of $C-1 \mathbf{e}, 13.8 \mathrm{kcal} / \mathrm{mol}$ very well.

The subsequent ethylene coordination to $\mathbf{9}^{\prime}$ is calculated as an exothermic reaction by $12.8 \mathrm{kcal} / \mathrm{mol}$, and the corresponding activation energy is $5.2 \mathrm{kcal} / \mathrm{mol}$ (Scheme 7). In contrast, the energy difference and activation energy for norbornene coordination to $\mathbf{9}^{\prime}$ were calculated as -2.8 and $14.0 \mathrm{kcal} / \mathrm{mol}$. Apparently, the process of ethylene coordination to $\mathbf{9}^{\prime}$ is substantially favored after the $\mathrm{N}$-insertion reaction, thereby supporting the alternating copolymerization. 


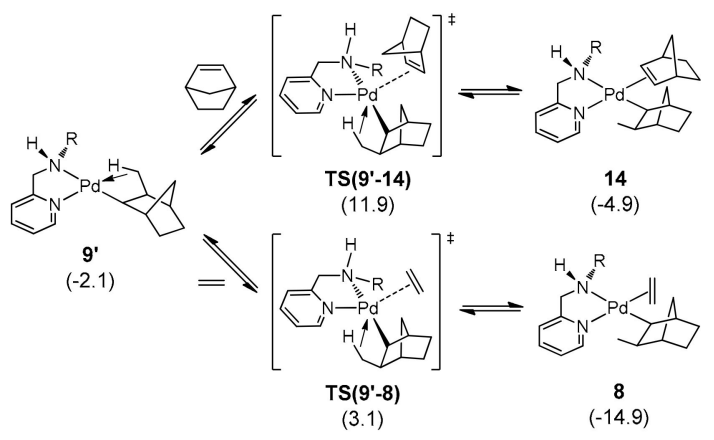

Scheme 7. Coordination pathway of ethylene or norbornene for $\gamma$-agostic intermediate 9' $(\mathrm{E}+\mathrm{ZPE}$, $\mathrm{kcal} / \mathrm{mol})$. ( $\left.\mathrm{R}=2,6-{ }^{i} \operatorname{Pr}_{2} \mathrm{C}_{6} \mathrm{H}_{3}\right)$.

\subsubsection{Ethylene and Norbornene Insertion into $\left(\mathrm{C}_{2} \mathrm{H}_{4}\right) \mathrm{Pd}-\mathrm{C}_{7} \mathrm{H}_{10} \mathrm{Me}$}

The energy profiles for ethylene and norbornene insertion processes from $\mathbf{8}$ and $\mathbf{8}^{\prime}$ are illustrated in Figure 5. The transition structure TS $\left(\mathbf{8}^{\prime}-\mathbf{1 3}^{\prime}\right)$ in the cis-form is $2.0 \mathrm{kcal} / \mathrm{mol}$ lower than $\mathbf{T S}(\mathbf{8}-\mathbf{1 3})$, thus the activation barrier is $3.4 \mathrm{kcal} / \mathrm{mol}$ lower, supporting the kinetic results (red line in Figure 5). As a consequence, one may propose the thermodynamically more stable isomer $\mathbf{8}$ converts to $\mathbf{8}^{\prime}$, followed by ethylene insertion to form $1 \mathbf{3}^{\prime}$, confirming the alternating COC formation.

The $\mathrm{N}$-insertion reactions from $\mathbf{8}$ and $\mathbf{8}^{\prime}$ are found to go through the pathways similar to those started from $\mathbf{6}$ and $\mathbf{6}^{\prime}$. However, the activation energies of $\mathrm{N}$-coordinating steps are 26.2 (via $T$-form) and 22.4 (via $C$-form) $\mathrm{kcal} / \mathrm{mol}$, much higher than the cases for $\mathbf{6}$ and $\mathbf{6}^{\prime}$. The process for the $C$-form still has a smaller energy barrier, although not enough to make competition with the E-insertion. The successive $\mathrm{N}$-insertions appear to achieve the NN-diads in the racemic form, and also agree with the experimental results.

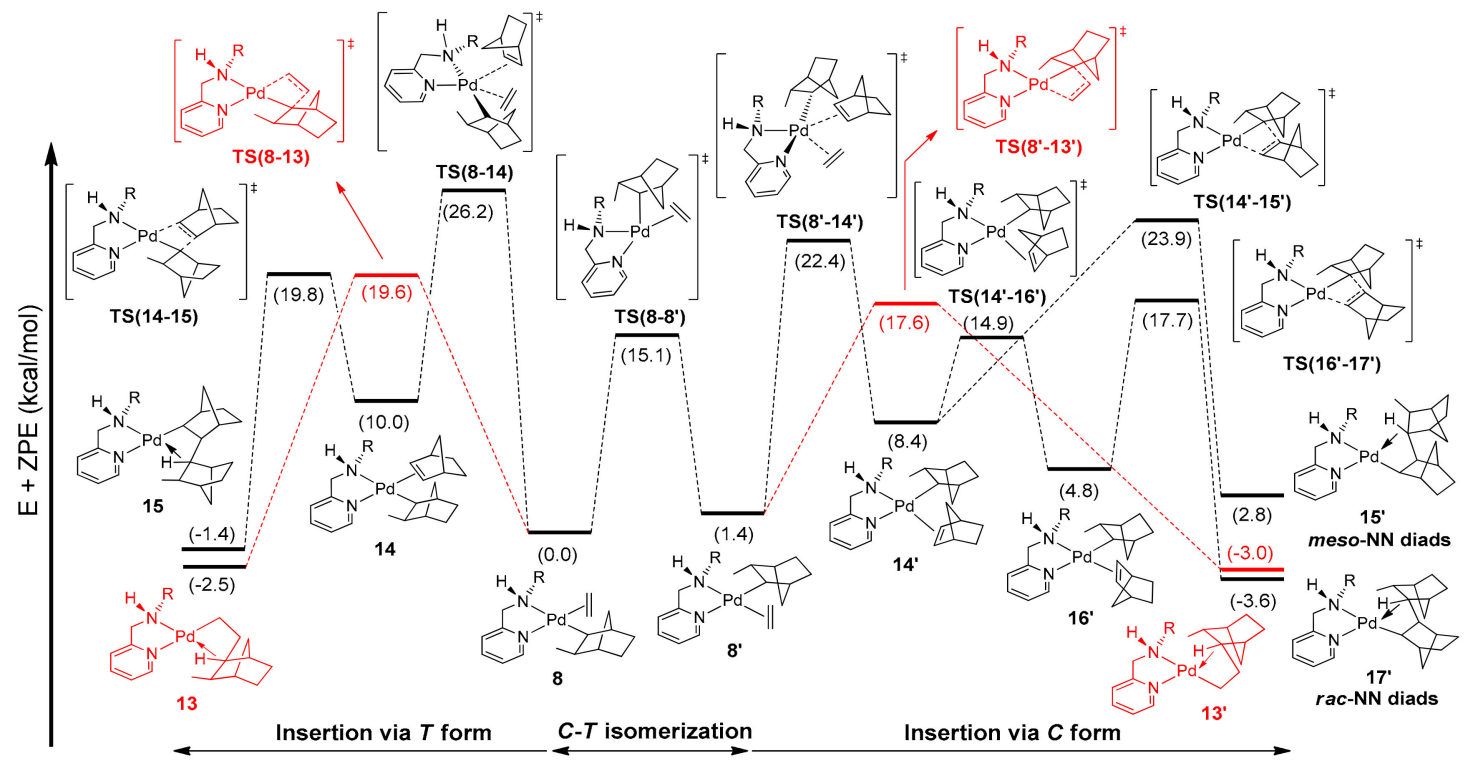

Figure 5. Energy profile for isomerization, ethylene and norbornene propagation reaction of $\mathbf{8}$ and $\mathbf{8}^{\prime}$ $(\mathrm{E}+\mathrm{ZPE}, \mathrm{kcal} / \mathrm{mol}) .\left(\mathrm{R}=2,6-{ }^{i} \operatorname{Pr}_{2} \mathrm{C}_{6} \mathrm{H}_{3}\right)$.

\subsubsection{Mechanism of Alternating E-N Copolymerization}

The structure-reactivity relationship of alternating E-N copolymerization may be illustrated as the catalytic cycle, shown in Scheme 8. 


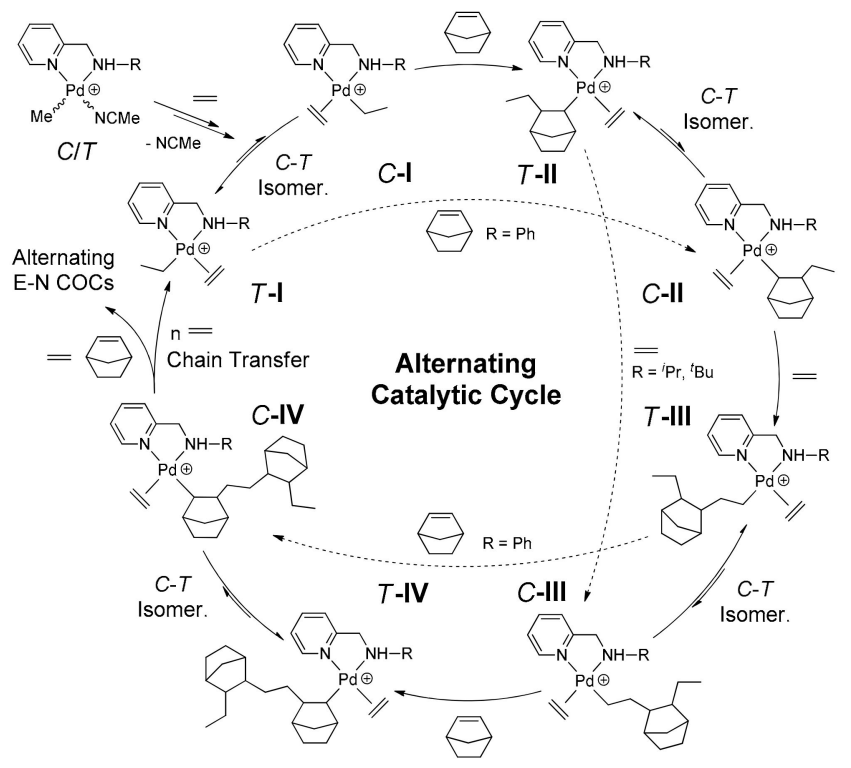

Scheme 8. Alternating Catalytic Cycle of E-N Copolymerization. (Solid line: $\mathrm{R}=2,6-\mathrm{Me}_{2} \mathrm{C}_{6} \mathrm{H}_{3}$, 2,6- ${ }^{i} \mathrm{Pr}_{2} \mathrm{C}_{6} \mathrm{H}_{3}$; dash line: $\left.\mathrm{R}={ }^{i} \mathrm{Pr},{ }^{t} \mathrm{Bu}, \mathrm{Ph}\right)$.

The resting states of $T-\mathbf{I}$ and C-I, representing the E-last-inserted intermediates, are the result of chain transfer. In the major cycle, the C-I reacting with norbornene is favored to yield T-II, which prefers to isomerize to $C$-II. The $C$-II undergoes facile E-insertion to give $T$-III, which prefers to isomerize to $C$-III, then $T$-IV and $C$-IV, and so on. The E-N alternating configurations thus may be achieved.

The rapid isomerization between $T$-I and C-I equilibrates, but is less likely to go to $C$-II from $T$-I. In the equilibrium between $T$-II and C-II, the former one is predominant because of the steric hindrance between the norbornyl and amino moieties. The $T$-II can alternatively convert to $C$-III too, via E-insertion. In the case of T-III, instead of isomerizes to C-III, it may undergo E-insertion to yield C-IV. Such pathways will also achieve E-N alternating configurations.

The successive $\mathrm{N}$-insertion would have a chance to take place in the $C$-II species to give racemic norbornene diads, particularly with high norbornene feeding. The $T$-II species unlikely proceeds via such a process, due to its disfavored steric effect. The successive E-insertion may also take place in the C-III. Such results were indeed observed under the conditions of high pressure of ethylene and low feeding with norbornene.

One may notice that the equilibria of geometrical isomerizations allow the catalysts to choose the more facile pathway of insertion. For the N-last-inserted species such as II and IV, the cis-isomers that undergo E-insertion will be predominant. And, for the E-last-inserted species as I and III, N-insertion may occur in either isomer. The control factor is mainly attributed to the steric effect.

Of course, competitions are always available when the kinetic conditions vary upon the reaction course. The formation of $\mathrm{N}$-diads or even $\mathrm{N}$-triad, and E-polyads or branches, had been indeed observed by ${ }^{13} \mathrm{C}-\mathrm{NMR}$. With the $\mathrm{N}$-feeding in the region of 6-79 $\mathrm{mol} \%$, the produced COCs containing norbornene units in $42.0-59.6 \%$ and the alternating compositions of $\mathrm{E}-\mathrm{N}$ are calculated as $70.4-94.2 \%$ (Table S1) [80]. One may conclude that the alternating copolymerization is of a more general situation.

Comparing with the catalytic E-N copolymerization using diimino palladium catalysts, in which 5-80 mol \% norbornene-feeding resulted in the norbornene contents are ranged in $9-60 \%$ in the COCs, the hemilabile unsymmetric amino-pyridine ligands in this study provide unprecedented examples that can afford selective isomerization-controlling olefin-insertions, and lead to high norbornene content as well as a high percentage of alternating E-N microstructure in the COCs. 
The activity data, norbornene contents, and norbornene blocks, with alternating percentages in the COC products catalyzed by $\mathbf{1 a - e}$, are collected in Table 5. All data for $\mathbf{1 d}$ and $\mathbf{1 e}$ are generally comparable. Complexes 1a,b,c show substantially lower activity; however, slightly less or nearly comparable results in the norbornene contents and alternating compositions were acquired compared to those of $\mathbf{1 d}$,e. The unusually high percentages of N-block for 1c may be blamed on its relatively large $k_{\mathrm{N}}^{T}$ and $k_{\mathrm{NN}}^{T}$.

Table 5. Norbornene blocks of E-N copolymers catalyzed by 1a-1e. ${ }^{\text {a }}$

\begin{tabular}{|c|c|c|c|c|c|c|}
\hline Cat & Act. $^{b}$ & $\mathrm{NB}_{\text {coc }}{ }^{\mathrm{c}}(\mathrm{mol} \%)$ & Single $^{c}(\mathrm{~mol} \%)$ & $\operatorname{Diads}^{\mathrm{c}}(\mathrm{mol} \%)$ & Triads $^{\mathrm{c}}(\mathrm{mol} \%)$ & Alter. ${ }^{c}$ (mol \%) \\
\hline $1 \mathrm{a}$ & 14 & 44.0 & 33.7 & 6.9 & 3.4 & 76.6 \\
\hline $1 \mathrm{~b}$ & 5 & 42.9 & 39.0 & 3.9 & 0 & 81.9 \\
\hline $1 \mathrm{c}$ & 6 & 47.5 & 26.4 & 12.4 & 8.7 & 71.0 \\
\hline $1 d$ & 27 & 48.1 & 34.8 & 6.9 & 6.4 & 80.8 \\
\hline $1 \mathrm{e}$ & 28 & 49.0 & 38.7 & 6.1 & 4.2 & 86.3 \\
\hline
\end{tabular}

We accordingly ascribe that the activity depends on the initialization of $\mathrm{N}$-coordination, as well as the chain transfer or the termination steps. The N-block and alternating compositions depend on the propagation steps, due to N- and E-insertions. Apparently, the fundamental kinetics follow the relationship: $k_{\mathrm{EN}}>k_{\mathrm{NE}}>>k_{\mathrm{NN}}, k_{\mathrm{EE}}$, as well as the concentrations of the monomers. In addition, the critical isomerization equilibria should never be overlooked by viewing the distinct $C / T$ ratios for the resting complexes $\mathbf{5}^{\prime}$ and the precursors $\mathbf{1}$ and $\mathbf{2}$.

\section{Materials and Methods}

\subsection{Materials}

Commercially available reagents were purchased and used without further purification unless otherwise indicated. THF, diethyl ether, dichloromethane, hexane and toluene were dried by passage through an M. Braun solvent purification system (MB-SPS) prior to use. Acetonitrile was distilled over anhydrous $\mathrm{CaH}_{2}$. All manipulations of air-sensitive material were performed under a nitrogen atmosphere either in a glove box or by standard Schlenk techniques. The preparation of $\left[\left(\mathrm{N}^{\wedge} \mathrm{N}\right) \mathrm{PdMe}(\mathrm{NCMe})\right]\left[\mathrm{BF}_{4}\right](1 \mathrm{a}-\mathrm{e})$ was described in our previous work [80].

\subsection{Measurements}

The NMR spectra were measured on a Bruker DPX-400, AVIII-400 or DMX-500 spectrometer. The corresponding frequencies for ${ }^{13} \mathrm{C}-\mathrm{NMR}$ spectra were 100.625 and $125.753 \mathrm{MHz}$, respectively. Values upfield of ${ }^{1} \mathrm{H}$ - and ${ }^{13} \mathrm{C}$ - data were given in $\delta(\mathrm{ppm})$ relative to chloroform in $\mathrm{CDCl}_{3}\left(7.24, \mathrm{CHCl}_{3}\right.$; 77.0, $\mathrm{CHCl}_{3}$ ) or to benzene in $\mathrm{d}_{6}$-benzene $\left(7.15, \mathrm{C}_{6} \mathrm{H}_{6} ; 128.7, \mathrm{C}_{6} \mathrm{H}_{6}\right)$. To have good integration data, the ${ }^{13} \mathrm{C}$ NMR spectra of copolymers were obtained at $100.625 \mathrm{MHz}$ in $\mathrm{CDCl}_{3}$ or $\mathrm{C}_{6} \mathrm{D}_{6}$ using inverse gated proton decoupling with 30 degree pluse and $3 \mathrm{~s}$ delay between the pluses. The NMR probe temperature for kinetic analysis was calibrated by using methanol standard (183-273 K) before the measurement. Assignments are based on ${ }^{1} \mathrm{H}$ - and ${ }^{13} \mathrm{C}-\mathrm{NMR}$ spectroscopy with COSY, NOESY and HSQC techniques. High-resolution mass spectrometric analyses were collected on a WATERS LCT Premier XE spectrometer. Elemental analysis was done on a Thermo Scientific FLASH 2000 CHNS analyzer. Gel permeation chromatography (GPC) was performed in toluene at $40{ }^{\circ} \mathrm{C}$ using a Kratos model spectroflow 400 equipped with PL-mixed D exclusion limit $400 \mathrm{k}$ columns, and the polystyrene calibration curve was used for analyses. Differential scanning calorimetry was measured under a continuous nitrogen purge $(20 \mathrm{~mL} / \mathrm{min})$ on a Perkin-Elmer Pyris 6 DSC instrument. The data were gathered on the secondary heating cycle using a heating and cooling scan rate of $10^{\circ} \mathrm{C} / \mathrm{min}$. 


\section{Conclusions}

This article reports detailed kinetics and a comprehensive mechanistic study for the catalytic alternating copolymerization of norbornene and ethylene, with use of the precursors (methylpalladium(II) cations (1a-e) bearing hemilabile bidentate of $\alpha$-amino-pyridines).

The kinetic studies evidence that the key resting states are likely to be the ethyl(ethylene)palladium complexes $\left(\mathbf{5} \mathbf{a}^{\prime}-\mathbf{e}^{\prime}\right)$. The kinetic data of insertion reactions for $\mathbf{1 a}-\mathbf{e}$ reveal that the catalytic cycle is predominated by the $\mathrm{N}$-insertion reactions, in which the $\mathrm{N}$-coordination is rate-determining. The $\mathrm{N}$-insertion in the $C$-isomer is significantly more facial $\left(k_{\mathrm{N}}{ }^{C-1 e} / k_{\mathrm{N}}{ }^{T-1 e}=143\right.$ at $\left.263 \mathrm{~K}\right)$, and the feasible geometrical isomerization is mainly controlled by the steric effects, cooperatively achieving the alternating $\mathrm{N}-\mathrm{E}$ copolmerization.

The DFT calculations not only show consistent results with the kinetic measurements, but also afford a complimentary mechanistic understanding. The calculations for $C-8^{\prime}$ also provide the favored E-insertion. The successive $\mathrm{N}$-insertion in $\mathrm{C}^{-8^{\prime}}$ will lead to racemic $\mathrm{N}$-block.

This study thus is good example, of which the structure-reactivity relationship may be fine-tuned by steric control. The hemilabile unsymmetric bidentate ligand of $\alpha$-amino-pyridine on the square planar organopalladium(II) cations demonstrate reactivities of convenient geometric isomerization and isomer-differentiated kinetic selectivity towards fundamental olefin-insertion. Such an unusual combination achieves the catalysis of COC-formation, with a high percentage of alternating microstructure.

Supplementary Materials: Supplementary materials are available online. Syntheses and characterizations of complexes, crystallographic data, and CIF files of $T-2 \mathbf{b}$ and $C-2 \mathbf{e}$, kinetic data of isomerization, ethylene, and norbornene insertion reactions, ${ }^{13} \mathrm{C}-\mathrm{NMR}$ spectra of COCs and theoretical calculation details.

Acknowledgments: We thank the Ministry of Science and Technology of Taiwan, ROC, the NSC-NWO joint project, and Kaohsiung Medical University for financial support (project numbers: NSC95-2911-I-002-087, NSC101-2113-M-002-011-MY2, MOST106-2113-M-037-007 and KMU-Q106003).

Author Contributions: Kuo-Hsuan Yu; Yu Wang; Shiuh-Tzung Liu and Jwu-Ting Chen designed the experiments. Kuo-Hsuan Yu and Yuan-Chung Cheng participated in the computational design. Kuo-Hsuan Yu; Shou-Ling Huang and Yi-Hung Liu performed the experiments. Kuo-Hsuan Yu and Ya-Fan Lin were responsible for the data analysis and the interpretation of results. Kuo-Hsuan Yu, Ya-Fan Lin and Jwu-Ting Chen wrote the manuscript.

Conflicts of Interest: The authors declare no conflict of interest.

\section{References}

1. Kaminsky, W.; Bark, A.; Arndt-Rosenau, M. New polymers by homogenous zirconocene/aluminoxane catalysts. Chem. Macromol. Symp. 1991, 47, 83-93. [CrossRef]

2. Cherdron, H.; Brekner, M.-J.; Osan, F. Cycloolefin-copolymere: Eine neue klasse transparenter thermoplaste. Angew. Makromol. Chem. 1994, 223, 121-133. [CrossRef]

3. Lamonte, R.R.; McNally, D. Cyclic olefin copolymers. Adv. Mater. Process 2001, 3, 1-4.

4. Kaminsky, W. Olefin polymerization catalyzed by metallocenes. Adv. Catal. 2001, 46, 89-159.

5. Nunes, P.S.; Ohlsson, P.D.; Ordeig, O.; Kutter, J.P. Cyclic olefin polymers: Emerging materials for lab-on-a-chip applications. Microfluid Nanofluid 2010, 9, 145-161. [CrossRef]

6. Boggioni, L.; Tritto, I. State of the art of cyclic olefin polymers. MRS Bull. 2013, 38, 245-251. [CrossRef]

7. Hasan, T.; Ikeda, T.; Shiono, T.J. Homo- and Copolymerization of Norbornene Derivatives with Ethene by ansa-Fluorenylamidodimethyltitanium Activated with Methylaluminoxane. Polym. Sci. Part A Polym. Chem. 2007, 45, 4581-4587. [CrossRef]

8. Nishizawa, O.; Misaka, H.; Sakai, R.; Kakuchi, T.; Satoh, T. Copolymerization of Ethylene and Norbornene Using Cyclopentadienylzirconium Trichloride Activated by Isobutyl-Modified Methylaluminoxane. J. Polym. Sci. Part A Polym. Chem. 2008, 46, 7411-7418. [CrossRef]

9. Sudhakar, P.J. Appreciable Norbornene Incorporation in the Copolymerization of Ethylene/Norbornene Using Titanium Catalysts Containing Trianionic $\mathrm{N}\left[\mathrm{CH}_{2} \mathrm{CH}(\mathrm{Ph}) \mathrm{O}_{3}{ }^{3-}\right.$ Ligands. Polym. Sci. Part A Polym. Chem. 2008, 46, 444-452. [CrossRef] 
10. Hu, H.; Gao, H.; Song, K.; Liu, F.; Long, J.; Zhang, L.; Zhu, F.; Wu, Q. Novel bis(benzoin) titanium catalyst for homo- and copolymerization of norbornene with ethylene: Synthesis, characterization and catalytic properties. Polymer 2008, 49, 4552-4558. [CrossRef]

11. Long, Y.-Y.; Ye, W.-P.; Shi, X.-C.; Li, Y.-S.J. Living Copolymerization of Ethylene with Norbornene Mediated by Heteroligated (Salicylaldiminato)( $\beta$-enaminoketonato)Titanium Catalysts. Polym. Sci. Part A Polym. Chem. 2009, 47, 6072-6082. [CrossRef]

12. Gao, H.-Y.; Hu, H.; Wu, Q. High norbornene incorporation in ethylene-norbornene copolymerization with a bis( $\alpha$-alkyloxoimine) titanium-MAO catalyst. Sci. China Chem. 2010, 53, 1634-1640. [CrossRef]

13. Padmanabhan, S.; Vijayakrishna, K.; Mani, R. Copolymerization of ethylene and norbornene by zirconium complexes containing symmetrically tuned trianionic ligands. Polym. Bull. 2010, 65, 13-23. [CrossRef]

14. Cabrera, A.; Schneider, Y.; Valderrama, M.; Galland, G.B.; Rojas, R.S. Synthesis and Characterization of Materials Prepared via the Copolymerization of Ethylene with 1-Octadecene and Norbornene Using a [( $\pi$-Cyano-nacnac)Cp] Zirconium Complex. J. Polym. Sci. A Polym. Chem. 2011, 49, 1535-1542. [CrossRef]

15. Ravasio, A.; Boggioni, L.; Scalcione, G.; Bertini, F.; Piovani, D.; Tritto, I. Living Copolymerization of Ethylene with Norbornene by Fuorinated Enolato-Imine Titanium Catalyst. J. Polym. Sci. Part A Polym. Chem. 2012, 50, 3867-3874. [CrossRef]

16. Yang, G.; Hong, M.; Li, Y.; Yu, S. Synthesis of Novel Bis( $\beta$-enaminoketonato)titanium Catalyst with High Activity and Excellent Ability to Copolymerize Olefins. Macromol. Chem. Phys. 2012, 213, 2311-2318. [CrossRef]

17. Tritto, I.; Boggioni, L.; Ferro, D.R. Metallocene catalyzed ethene- and propene co-norbornene polymerization: Mechanisms from a detailed microstructural analysis. Coord. Chem. Rev. 2006, 250, 212-241. [CrossRef]

18. Ruchatz, D.; Fink, G. Ethene-Norbornene Copolymerization Using Homogenous Metallocene and Half-Sandwich Catalysts: Kinetics and Relationships between Catalyst Structure and Polymer Structure. 2. Comparative Study of Different Metallocene- and Half-Sandwich/Methylaluminoxane Catalysts and Analysis of the Copolymers by ${ }^{13} \mathrm{C}$ Nuclear Magnetic Resonance Spectroscopy. Macromolecules 1998, 31, 4674-4680. [PubMed]

19. Ruchatz, D.; Fink, G. Ethene-Norbornene Copolymerization with Homogeneous Metallocene and Half-Sandwich Catalysts: Kinetics and Relationships between Catalyst Structure and Polymer Structure. 4. Development of Molecular Weights. Macromolecules 1998, 31, 4684-4686. [CrossRef] [PubMed]

20. Tritto, I.; Marestin, C.; Boggioni, L.; Sacchi, M.C.; Brintzinger, H.-H.; Ferro, D.R. Stereoregular and Stereoirregular Alternating Ethylene-Norbornene Copolymers. Macromolecules 2001, 34, 5770-5777. [CrossRef]

21. Nomura, K.; Tsubota, M.; Fujiki, M. Efficient Ethylene/Norbornene Copolymerization by (Aryloxo)(indenyl)titanium(IV) Complexes-MAO Catalyst System. Macromolecules 2003, 36, 3797-3799. [CrossRef]

22. Yoshida, Y.; Mohri, J.-I.; Ishii, S.-I.; Mitani, M.; Saito, J.; Matsui, S.; Makio, H.; Nakano, T.; Tanaka, H.; Onda, M.; et al. Living Copolymerization of Ethylene with Norbornene Catalyzed by Bis(Pyrrolide-Imine) Titanium Complexes with MAO. J. Am. Chem. Soc. 2004, 126, 12023-12032. [CrossRef] [PubMed]

23. Yoshida, Y.; Matsui, S.; Fujita, T. Bis(pyrrolide-imine) Ti complexes with MAO: A new family of high performance catalysts for olefin polymerization. J. Organomet. Chem. 2005, 690, 4382-4397. [CrossRef]

24. Nomura, K.; Wang, W.; Fujiki, M.; Liu, J. Notable norbornene (NBE) incorporation in ethylene-NBE copolymerization catalysed by nonbridged half-titanocenes: Better correlation between NBE incorporation and coordination energy. Chem. Commun. 2006, 25, 2659-2661. [CrossRef] [PubMed]

25. Nomura, K.; Yamada, J.; Wang, W.; Liu, J. Effect of ketimide ligand for ethylene polymerization and ethylene/norbornene copolymerization catalyzed by (cyclopentadienyl)(ketimide)titanium complexes-MAO catalyst systems: Structural analysis for $\mathrm{Cp}^{*} \mathrm{TiCl}_{2}\left(\mathrm{~N}=\mathrm{CPh}_{2}\right)$. J. Organomet. Chem. 2007, 692, 4675-4682. [CrossRef]

26. Zuo, W.; Sun, W.-H.; Zhang, S.; Hao, P.; Shiga, A. Highly Active Ethylene Polymerization and Copolymerization with Norbornene Using Bis(imino-indolide) Titanium Dichloride-MAO system. J. Polym. Sci. Part A Polym. Chem. 2007, 45, 3415-3430. [CrossRef]

27. Gao, M.; Wang, C.; Sun, X.; Qian, C.; Ma, Z.; Bu, S.; Tang, Y.; Xie, Z. Ethylene-Norbornene Copolymerization by New Titanium Complexes Bearing Tridentate Ligands. Sidearm Effects on Catalytic Activity. Macromol. Rapid Commun. 2007, 28, 1511-1516. [CrossRef] 
28. Li, Y.; Gao, H.; Wu, Q. Homo-and Copolymerization of Ethylene and Norbornene with Bis( $\beta$-diketiminato) Titanium Complexes Activated with Methylaluminoxane. J. Polym. Sci. Part A Polym. Chem. 2008, 46, $93-101$. [CrossRef]

29. Yao, Z.; Lv, F.; Liu, S.-J.; Cao, K. Synthesis of Ethylene and Norbornene Copolymer with Metallocene Catalysts and Characteristic Analysis. J. Appl. Polym. Sci. 2008, 107, 286-291. [CrossRef]

30. Terao, H.; Iwashita, A.; Ishii, S.; Tanaka, H.; Yoshida, Y.; Mitani, M.; Fujita, T. Ethylene/Norbornene Copolymerization Behavior of Bis(phenoxy-imine) Ti Complexes Combined with MAO. Macromolecules 2009, 42, 4359-4361. [CrossRef]

31. Hong, M.; Wang, Y.-X.; Mu, H.-L.; Li, Y.-S. Efficient Synthesis of Hydroxylated Polyethylene via Copolymerization of Ethylene with 5-Norbornene-2-methanol Using Bis( $\beta$-enaminoketonato)titanium Catalysts. Organometallics 2011, 30, 4678-4686. [CrossRef]

32. Zhang, W.; Wang, Y.; Redshaw, C.; Hao, X.; Sun, W.-H. 2-Aldiminophenoxytitanium chloride complexes: Synthesis, characterization, and ethylene (co-)polymerization behavior. J. Organomet. Chem. 2012, 715, 119-128. [CrossRef]

33. Tao, P.; Mu, H.-L.; Liu, J.-Y.; Li, Y.-S. New Half-Sandwich Chromium(III) Complexes Bearing Phenoxy-Phosphine (Oxide) [O,P(=O)] Ligands: Synthesis, Structures, and Catalytic Properties for Ethylene (Co)Polymerization. Organometallics 2013, 32, 4805-4812. [CrossRef]

34. Nomura, K.; Bahuleyan, B.K.; Zhang, S.; Sharma, P.M.V.; Katao, S.; Igarashi, A.; Inagaki, A.; Tamm, M. Synthesis and Structural Analysis of (Imido)vanadium(V) Dichloride Complexes Containing Imidazolin-2-iminato- and Imidazolidin-2-iminato Ligands, and their Use as Catalyst Precursors for Ethylene (Co)polymerization. Inorg. Chem. 2014, 53, 607-623. [CrossRef] [PubMed]

35. Diteepeng, N.; Tang, X.; Hou, X.; Li, Y.-S.; Phomphrai, K.; Nomura, K. Ethylene polymerisation and ethylene/norbornene copolymerisation by using aryloxo-modified vanadium(V) complexes containing 2,6-difluoro-, dichloro-phenylimido complexes. Dalton Trans. 2015, 44, 12273-12281. [CrossRef] [PubMed]

36. Pei, L.; Tang, Y.; Gao, H. Homo- and Copolymerization of Ethylene and Norbornene with Anilido-Imine Chromium Catalysts. Polymers 2016, 8, 69. [CrossRef]

37. Yoon, K.-B.; Choi, Y.S.; Noh, S.K.; Lee, D.-H. Ethylene/Norbornene Copolymerization with $i \operatorname{Pr}(\mathrm{Cp})(\mathrm{Flu}) \mathrm{ZrCl} 2$ Catalyst: Effect of MAO Cocatalyst and $3^{\text {rd }}$ Monomer. Macromol. Symp. 2007, 260, 27-33. [CrossRef]

38. Bredeau, S.; Boggioni, L.; Bertini, F.; Tritto, I.; Monteverde, F.; Alexandre, M.; Dubois, P. Ethylene-Norbornene Copolymerization by Carbon Nanotube-Supported Metallocene Catalysis: Generation of High-Performance Polyolefinic Nanocomposites. Macromol. Rapid Commun. 2007, 28, 822-827. [CrossRef]

39. Gentil, S.; Pirio, N.; Meunier, P.; Gallou, F.; Paquette, L.A. Ethene/Norbornene Copolymerization with (Isodicyclopentadienyl)titanium Complex-MAO Catalyst. Collect. Czech. Chem. Commun. 2007, 72, 697-702.

40. Tada, T.; Cai, Z.; Nakayama, Y.; Shiono, T. Efficient Molecular Weight Control with Trialkylaluminum

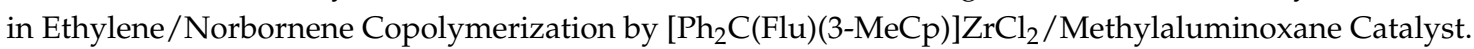
Macromol. Chem. Phys. 2010, 211, 2132-2137. [CrossRef]

41. Huang, W.; Li, B.; Wang, Y.; Zhang, W.; Wang, L.; Li, Y.; Sun, W.-H.; Redshaw, C. Synthesis, characterization and ethylene (co-)polymerization behavior of half-titanocene 2-(1-(arylimino)ethyl)quinolin-8-olate chlorides. Catal. Sci. Technol. 2011, 1, 1208-1215. [CrossRef]

42. Zou, Y.; Wang, D.; Wurst, K.; Kühnel, C.; Reinhardt, I.; Decker, U.; Gurram, V.; Camadanli, S.; Buchmeiser, M.R. Group 4 Dimethylsilylenebisamido Complexes Bearing the 6-[2-(Diethylboryl)phenyl]pyrid-2-yl Motif: Synthesis and Use in Tandem Ring Opening Metathesis/Vinyl-Insertion Copolymerization of Cyclic Olefins with Ethylene. Chem. Eur. J. 2011, 17, 13832-13846. [CrossRef] [PubMed]

43. Carvalhoa, M.F.N.N.; Galvão, A.M.; Kredatusová, J.; Merna, J.; Pinheiro, P.F.; Salema, M.M. Synthesis and catalytic activity of camphor titanium complexes. Inorg. Chim. Acta 2012, 383, 244-249. [CrossRef]

44. Hong, M.; Cui, L.; Liu, S.; Li, Y. Synthesis of Novel Cyclic Olefin Copolymer (COC) with High Performance via Effective Copolymerization of Ethylene with Bulky Cyclic Olefin. Macromolecules 2012, 45, 5397-5402. [CrossRef]

45. Tang, X.-Y.; Wang, Y.-X.; Li, B.-X.; Liu, J.-Y.; Li, Y.-S. Highly Efficient Ethylene/Norbornene Copolymerization by $o$-Di(phenyl)phosphanylphenolate-Based Half-Titanocene Complexes. J. Polym. Sci. Part A Polym. Chem. 2013, 51, 1585-1594. [CrossRef] 
46. Tang, X.-Y.; Liu, J.-Y.; Li, Y.-S. Phosphine-Thiophenolate Half-Titanocene Chlorides: Synthesis, Structure, and Their Application in Ethylene (Co-)Polymerization. Catalysts 2013, 3, 261-275. [CrossRef]

47. Tritto, I.; Boggioni, L.; Scalcione, G.; Sidari, D.; Galotto, N.G. Novel norbornene copolymers with transition metal catalysts. J. Organomet. Chem. 2015, 798, 367-374. [CrossRef]

48. Zhao, W.; Yan, Q.; Tsutsumi, K.; Nomura, K. Efficient Norbornene (NBE) Incorporation in Ethylene/NBE Copolymerization by Half-Titanocene Catalysts Containing Chlorinated Aryloxo Ligands. Organometallics 2016, 35, 1895-1905. [CrossRef]

49. Zhao, W.; Nomura, K. Design of Efficient Molecular Catalysts for Synthesis of Cyclic Olefin Copolymers (COC) by Copolymerization of Ethylene and $\alpha$-Olefins with Norbornene or Tetracyclododecene. Catalysts 2016, 6, 175. [CrossRef]

50. Li, Y.; Yang, J.; Wang, B.; Li, Y. Efficient copolymerization of ethylene with norbornene or its derivatives using half-metallocene zirconium (IV) catalysts. RSC Adv. 2016, 6, 59590-59599. [CrossRef]

51. Ruchatz, D.; Fink, G. Ethene-Norbornene Copolymerization Using Homogenous Metallocene and Half-Sandwich Catalysts: Kinetics and Relationships between Catalyst Structure and Polymer Structure. 1. Kinetics of the Ethene-Norbornene Copolymerization Using the [(Isopropylidene) $\left(\eta^{5}\right.$-inden-1-ylidene- $\eta^{5}$-cyclopentadienyl)]zirconium Dichloride/Methylaluminoxane Catalyst. Macromolecules 1998, 31, 4669-4673.

52. Ruchatz, D.; Fink, G. Ethene-Norbornene Copolymerization with Homogeneous Metallocene and Half-Sandwich Catalysts: Kinetics and Relationships between Catalyst Structure and Polymer Structure.

3. Copolymerization Parameters and Copolymerization Diagrams. Macromolecules 1998, 31, 4681-4683. [CrossRef] [PubMed]

53. McKnight, A.L.; Waymouth, R.M. Ethylene/Norbornene Copolymerizations with Titanium CpA Catalysts. Macromolecules 1999, 32, 2816-2825. [CrossRef]

54. Kaminsky, W.; Beulich, I.; Arndt-Rosenau, M. Copolymerization of Ethene with Cyclic and Other Sterically Hindered Olefins. Macromol. Symp. 2001, 173, 211-225. [CrossRef]

55. Tritto, I.; Boggioni, L.; Jansen, J.C.; Thorshaug, K.; Sacchi, M.C.; Ferro, D.R. Ethylene-Norbornene Copolymers from Metallocene-Based Catalysts: Microstructure at Tetrad Level and Reactivity Ratios. Macromolecules 2002, 35, 616-623. [CrossRef]

56. Park, S.Y.; Choi, K.Y.; Song, K.H.; Jeong, B.G. Kinetic Modeling of Ethylene-Norbornene Copolymerization Using Homogeneous Metallocene Catalysts. Macromolecules 2003, 36, 4216-4225. [CrossRef]

57. Hasan, T.; Ikeda, T.; Shiono, T. Ethene-Norbornene Copolymer with High Norbornene Content Produced by ansa-Fluorenylamidodimethyltitanium Complex Using a Suitable Activator. Macromolecules 2004, 37, 8503-8509. [CrossRef]

58. Tritto, I.; Boggioni, L.; Ferro, D.R. Alternating Isotactic Ethylene-Norbornene Copolymers by $\mathrm{C}_{1}$-Symmetric Metallocenes: Determination of the Copolymerization Parameters and Mechanistic Considerations on the Basis of Pentad Analysis. Macromolecules 2004, 37, 9681-9693. [CrossRef]

59. Vijayakrishna, K.; Sundararajan, G. Non-Cp type titanium precatalysts for ethylene/norbornene copolymerization. Polymer 2006, 47, 8289-8296. [CrossRef]

60. Park, S.Y.; Lee, J.; Choi, K.Y. A Reduced Third Order Markov Model for Ethylene-Norbornene Copolymerization Kinetics with Homogeneous Metallocene Catalysts. Macromol. React. Eng. 2007, 1, 68-77. [CrossRef]

61. Ni, J.; Lü, C.; Zhang, Y.; Liu, Z.; Mu, Y. Norbornene polymerization and ethylene/norbornene copolymerization catalyzed by constrained geometry cyclopentadienyl-phenoxytitanium catalysts. Polymer 2008, 49, 211-216. [CrossRef]

62. Li, H.; Li, J.; Zhang, Y.; Mu, Y. Homo- and copolymerization of 5-ethylidene-2-norbornene with ethylene by $\left[2-\mathrm{C}_{5} \mathrm{Me}_{4}-4,6-\mathrm{tBu}_{2} \mathrm{C}_{6} \mathrm{H}_{2} \mathrm{O}\right] \mathrm{TiCl}_{2} / \mathrm{AliBu}_{3} / \mathrm{Ph}_{3} \mathrm{CB}\left(\mathrm{C}_{6} \mathrm{~F}_{5}\right)_{4}$ catalyst system and epoxidation of the resulting copolymer Polymer 2008, 49, 2839-2844. Polymer 2008, 49, 2839-2844. [CrossRef]

63. Ravasio, A.; Boggioni, L.; Tritto, I. Copolymerization of Ethylene with Norbornene by Neutral Aryl Phosphine Sulfonate Palladium Catalyst. Macromolecules 2011, 44, 4180-4186. [CrossRef]

64. Diamanti, S.J.; Ghosh, P.; Shimizu, F.; Bazan, G.C. Ethylene Homopolymerization and Copolymerization with Functionalized 5-Norbornen-2-yl Monomers by a Novel Nickel Catalyst System. Macromolecules 2003, 36, 9731-9735. [CrossRef] 
65. Joe, S.S.D.J.; Na, S.J.; Park, Y.-W.; Choi, C.H.; Lee, B.Y. Ethylene/Polar Norbornene Copolymerizations by Bimetallic Salicylaldimine-Nickel Catalysts. Macromolecules 2005, 38, 10027-10033.

66. Wang, L.; Li, Y.; Zhu, F.; Wu, Q. Copolymerization of Norbornene and Methyl Acrylate by $\beta$-ketoiminato Palladium Complexes/MAO. Polym. Bull. 2006, 57, 73-81. [CrossRef]

67. Liu, S.; Borkar, S.; Newsham, D.; Yennawar, H.; Sen, A. Synthesis of Palladium Complexes with an Anionic $\mathrm{P} \sim \mathrm{O}$ Chelate and Their Use in Copolymerization of Ethene with Functionalized Norbornene Derivatives: Unusual Functionality Tolerance. Organometallics 2007, 26, 210-216. [CrossRef]

68. Chen, Z.; Mesgar, M.; White, P.S.; Daugulis, O.; Brookhart, M. Synthesis of Branched Ultrahigh-Molecular-Weight Polyethylene Using Highly Active Neutral, Single-Component Ni(II) Catalysts. ACS Catal. 2015, 5, 631-636. [CrossRef]

69. Chen, Z.; Allen, K.E.; White, P.S.; Daugulis, O.; Brookhart, M. Synthesis of Branched Polyethylene with "Half-Sandwich" Pyridine-Imine Nickel Complexes. Organometallics 2016, 35, 1756-1760. [CrossRef]

70. Bezier, D.; Daugulis, O.; Brookhart, M. Oligomerization of Ethylene Using a Diphosphine Palladium Catalyst. Organometallics 2017, 36, 443-447. [CrossRef]

71. Ji, P.; Guo, L.; Hu, X.; Li, W. Ethylene polymerization by salicylaldimine Nickel(II) complexes derived from arylnaphthylamine. J. Polym. Res. 2017, 24, 30-38. [CrossRef]

72. Huang, Y.; He, J.; Liu, Z.; Cai, G.; Zhang, S.; Li, X. A highly active chiral (S,S)-bis(oxazoline) Pd(II) alkyl complex/activator catalytic system for vinyl polymerization of norbornene in air and water. Poly. Chem. 2017. [CrossRef]

73. Brekner, M.-J.; Osan, F.; Rohrmann, J.; Antberg, M.U.S. Process for the Preparation of Chemically Homogeneous Cycloolefin Copolymers. U.S. Patent 5,324,801, 28 January 1994.

74. Benedikt, G.M.; Elce, E.; Goodall, B.L.; Kalamarides, H.A.; McIntosh, L.H.; Rhodes, L.F.; Selvy, K.T. Copolymerization of Ethene with Norbornene Derivatives Using Neutral Nickel Catalysts. Macromolecules 2002, 35, 8978-8988. [CrossRef]

75. Kiesewetter, J.; Kaminsky, W. Ethene/Norbornene Copolymerization with Palladium(II) $\alpha$-Diimine Catalysts: From Ligand Screening to Discrete Catalyst Species. Chem. Eur. J. 2003, 9, 1750-1758. [CrossRef] [PubMed]

76. Kiesewetter, J.; Arikan, B.; Kaminsky, W. Copolymerization of ethene with norbornene using palladium(II) $\alpha$-diimine catalysts: Influence of feed composition, polymerization temperature, and ligand structure on copolymer properties and microstructure. Polymer 2006, 47, 3302-3314. [CrossRef]

77. Rodriguez, B.A.; Delferro, M.; Marks, T.J. Neutral Bimetallic Nickel(II) Phenoxyiminato Catalysts for Highly Branched Polyethylenes and Ethylene-Norbornene Copolymerizations. Organometallics 2008, 27, 2166-2168. [CrossRef]

78. Tritto, I.; Boggioni, L.; Ravasio, A.; Scalcione, G. Cycloolefin Copolymers by Early and Late Transition Metal Catalysts. Macromol. React. Eng. 2013, 7, 91-97. [CrossRef]

79. Gao, H.Y.; Liu, Y.; Li, G.L.; Xiao, Z.F.; Liang, G.D.; Wu, Q. Catalytic synthesis of polyethylene-block-polynorbornene copolymers using a living polymerization nickel catalyst. Polym. Chem. 2014, 5, 6012-6018. [CrossRef]

80. Lin, Y.-C.; Yu, K.-H.; Huang, S.-L.; Liu, Y.-H.; Wang, Y.; Liu, S.-T.; Chen, J.-T. Alternating ethylene-norbornene copolymerization catalyzed by cationic organopalladium complexes bearing hemilabile bidentate ligands of $\alpha$-amino-pyridines. Dalton Trans. 2009, 41, 9058-9067. [CrossRef] [PubMed]

81. Lim, N.K.; Arndtsen, B.A. Novel Coupling of Two Mechanistically Distinct Polymerizations on a Single Metal Center: Palladium-Mediated Synthesis of Poly(norbornene)-Poly(THF) Block Copolymers. Macromolecules 2000, 33, 2305-2307. [CrossRef]

82. Reddy, K.R.; Surekha, K.; Lee, G.-H.; Peng, S.-M.; Chen, J.-T.; Liu, S.-T. Study of Insertion of Olefins and/or Carbon Monoxide into Phosphine-Imine Palladium Methyl Complexes. Organometallics 2001, 20, 1292-1299. [CrossRef]

83. Setsune, J.-I.; Yamauchi, T.; Tanikawa, S.; Hirose, Y.; Watanabe, J.-Y. Insertion of CO and Alkenes into the (methyl)Pd Complexes of the Bidentate Porphyrin Ligand. Organometallics 2004, 23, 6058-6065. [CrossRef]

84. Agostinho, M.; Braunstein, P.; Welter, R. Phosphinito- and phosphonito-oxazoline Pd(II) complexes as CO/ethylene insertion intermediates: synthesis and structural characterization. Dalton Trans. 2007, 7, 759-770. [CrossRef] [PubMed] 
85. Lee, J.-J.; Yang, F.-Z.; Lin, Y.-F.; Chang, Y.-C.; Yu, K.-H.; Chang, M.-C.; Lee, G.-H.; Liu, Y.-H.; Wang, Y.; Liu, S.-T.; et al. Unsymmetrical bidentate ligands of $\alpha$-aminoaldimines leading to sterically controlled selectivity of geometrical isomerism in square planar coordination. Dalton Trans. 2008, 43, 5945-5956. [CrossRef] [PubMed]

86. Amatore, C.; Catellani, M.; Deledda, S.; Jutand, A.; Motti, E. Rates of the Oxidative Addition of Benzyl Halides to a Metallacyclic Palladium(II) Complex and of the Reductive Elimination from a Benzyl-Palladium (IV) Complex. Organometallics 2008, 27, 4549-4554. [CrossRef]

87. Walter, M.D.; White, P.S.; Brookhart, M. $\gamma$-Agostic interactions stabilize the propagating species in the vinyl addition polymerization of norbornene. Chem. Commun. 2009, 42, 6361-6363. [CrossRef] [PubMed]

88. Walter, M.D.; Moorhouse, R.A.; Urbin, S.A.; White, P.S.; Brookhart, M. $\gamma$-Agostic Species as Key Intermediates in the Vinyl Addition Polymerization of Norbornene with Cationic (allyl)Pd Catalysts: Synthesis and Mechanistic Insights. J. Am. Chem. Soc. 2009, 131, 9055-9069. [CrossRef] [PubMed]

89. Kang, M.; Sen, A. Reaction of Palladium 1,5-Cyclooctadiene Alkyl Chloride with Norbornene Derivatives: Relevance to Metal-Catalyzed Addition Polymerization of Functionalized Norbornenes. Organometallics 2004, 23, 5396-5398. [CrossRef]

90. Vicente, J.; Arcas, A.; Fernández-Hernández, J.M.; Bautista, D. New Acetonyl Palladium(II) Complexes. Organometallics 2008, 27, 3978-3985. [CrossRef]

91. Takamiya, I.; Yamashita, M.; Nozaki, K. Syntheses of Ester-Substituted Norbornyl Palladium Complexes Ligated with ${ }^{t} \mathrm{Bu}_{3} P$ : Studies on the Insertion of exo- and endo-Monomers in the Ester-Substituted Norbornene Polymerization. Organometallics 2008, 27, 5347-5352. [CrossRef]

92. Dieck, H.; Svoboda, M. Metallierung einer nichtaktivierten Alkyl-Gruppe im Nickelkomplex. Chem. Ber. 1976, 109, 1657-1664. [CrossRef]

93. Tempel, D.J.; Johnson, L.K.; Huff, R.L.; White, P.S.; Brookhart, M. Mechanistic Studies of Pd(II)- $\alpha$-Diimine-Catalyzed Olefin Polymerizations. J. Am. Chem. Soc. 2000, 122, 6686-6700. [CrossRef]

94. Diez, V.; Cuevas, J.V.; García-Herbosa, G.; Aullón, G.; Charmant, J.P.H.; Carbayo, A.; Muñoz, A. ${ }^{1} \mathrm{H}$ NMR Direct Observation of Enantiomeric Exchange in Palladium(II) and Platinum(II) Complexes Containing $N, N^{\prime}$ Bidentate Aryl-pyridin-2-ylmethyl-amine Ligands. Inorg. Chem. 2007, 46, 568-577. [CrossRef] [PubMed]

95. Dell'Anna, M.M.; Giardina-Papa, D.; Ibáñez, S.; Martín, A.; Mastrorilli, P.; Nobile, C.F.; Peruzzini, M. Insertion of CO and Strained Olefins into Organometallic (Ferrocenylmethyl)phosphane Palladium Complexes. Eur. J. Inorg. Chem. 2009, 29, 4454-4463. [CrossRef]

96. Espenson, J.H. Chemical Kinetics and Reaction Mechanisms, 2nd ed.; McGraw-Hill: New York, NY, USA, 2002; pp. 156-160.

97. Gates, D.P.; Svejda, S.A.; Oñate, E.; Killian, C.M.; Johnson, L.K.; White, P.S.; Brookhart, M. Synthesis of Branched Polyethylene using ( $\alpha$-Diimine)nickel(II) Catalysts: Influence of Temperature, Ethylene Pressure, and Ligand Structure on Polymer Properties. Macromolecules 2000, 33, 2320-2334. [CrossRef]

98. Yang, F.-Z.; Wang, Y.-H.; Chang, M.-C.; Yu, K.-H.; Huang, S.-L.; Liu, Y.-H.; Wang, Y.; Liu, S.-T.; Chen, J.-T. Kinetic and Mechanistic Studies of Geometrical Isomerism in Neutral Square-Planar Methylpalladium Complexes Bearing Unsymmetrical Bidentate Ligands of $\alpha$-Aminoaldimines. Inorg. Chem. 2009, 48, 7639-7644. [CrossRef] [PubMed]

99. Johnson, L.K.; Killian, C.M.; Brookhart, M. New Pd(II)- and Ni(II)-Based Catalysts for Polymerization of Ethylene and $\alpha$-Olefins. J. Am. Chem. Soc. 1995, 117, 6414-6415. [CrossRef]

100. Johnson, L.K.; Mecking, S.; Brookhart, M. Copolymerization of Ethylene and Propylene with Functionalized Vinyl Monomers by Palladium(II) Catalysts. J. Am. Chem. Soc. 1996, 118, 267-268. [CrossRef]

101. Killian, C.M.; Tempel, D.J.; Johnson, L.K.; Brookhart, M. Living Polymerization of $\alpha$-Olefins Using $\mathrm{Ni}^{\mathrm{II}}-\alpha$-Diimine Catalysts. Synthesis of New Block Polymers Based on $\alpha$-Olefins. J. Am. Chem. Soc. 1996, 118, 11664-11665. [CrossRef]

102. Mecking, S.; Johnson, L.K.; Wang, L.; Brookhart, M. Mechanistic Studies of the Palladium-Catalyzed Copolymerization of Ethylene and $\alpha$-Olefins with Methyl Acrylate. J. Am. Chem. Soc. 1998, 120, 888-899. [CrossRef]

103. Berry, R.S. Correlation of Rates of Intramolecular Tunneling Processes, with Application to Some Group V Compounds. J. Chem. Phys. 1960, 32, 933-938. [CrossRef]

104. Ugi, I.; Marquarding, D.; Klusacek, H.; Gillespie, P.; Ramirez, F. Berry Pseudorotation and Turnstile Rotation. Acc. Chem. Res. 1971, 4, 288-296. [CrossRef] 
105. Casares, J.A.; Espinet, P. Dynamic Behavior of $\left[\mathrm{Pd}\left(\mathrm{C}_{6} \mathrm{~F}_{5}\right)_{2}\left(\mathrm{SPPy}_{n} \mathrm{Ph}_{3-n}\right)\right]$ Complexes: Evidence for a Turnstile Mechanism in Intramolecular Exchange. Inorg. Chem. 1997, 36, 5428-5431. [CrossRef]

106. Anderson, G.K.; Cross, R.J. Isomerisation Mechanisms of Square-Planar Complexes. Chem. Soc. Rev. 1980, 9 , 185-215. [CrossRef]

107. Ozawa, F.; Ito, T.; Nakamura, Y.; Yamamoto, A. Mechanisms of Thermal Decomposition of trans- and cis-Dialkylbis-(tertiary phosphine)palladium(II). Reductive Elimination and trans to cis Isomerization. Bull. Chem. Soc. Jpn. 1981, 54, 1868-1880. [CrossRef]

108. Pavonessa, R.S.; Trogler, W.C. Solvent-Dependent Reactions of Carbon Dioxide with a Platinum(II) Dihydride. Reversible Formation of a Platinum(II) Formatohydride and a Cationic Platinum(II) Dimer, $\left[\mathrm{Pt}_{2} \mathrm{H}_{3}\left(\mathrm{PEt}_{3}\right)_{4}\right]\left[\mathrm{HCO}_{2}\right]$. J. Am. Chem. Soc. 1982, 104, 3529-3530. [CrossRef]

109. Low, J.J.; Goddard III, W.A. Theoretical Studies of Oxidative Addition and Reductive Elimination. 3. C-H and C-C Reductive Coupling from Palladium and Platinum Bis(phosphine) Complexes. J. Am. Chem. Soc. 1986, 108, 6115-6128. [CrossRef]

110. Tatsumi, K.; Hoffmann, R.; Yamamoto, A.; Stille, J.K. Reductive Elimination of $\mathrm{d}^{8}$-Organotransition Metal Complexes. Bull. Chem. Soc. Jpn. 1981, 54, 1857-1867. [CrossRef]

111. Deubel, D.V.; Ziegler, T. Challenge of the Copolymerization of Olefins with N-Containing Polar Monomers. Systematic Screening of Nickel(II) and Palladium(II) Catalysts with Brookhart and Grubbs Ligands. 2. Chain-Propagation Barriers, Intrinsic Regioselectivity, and Curtin-Hammett Reactivity. Organometallics 2002, $21,4432-4441$.

112. Noda, S.; Nakamura, A.; Kochi, T.; Chung, L.W.; Morokuma, K.; Nozaki, K. Mechanistic Studies on the Formation of Linear Polyethylene Chain Catalyzed by Palladium Phosphine-Sulfonate Complexes: Experiment and Theoretical Studies. J. Am. Chem. Soc. 2009, 131, 14088-14100. [CrossRef] [PubMed]

113. Zheng, F.; Hutton, A.T.; van Sittert, C.G.C.E.; Moss, J.R.; Mapolie, S.F. Synthesis, structural characterization and cis-trans isomerization of novel (salicylaldiminato)platinum(II) complexes. Dalton Trans. 2013, 42, 11163-11179. [CrossRef] [PubMed]

114. Musaev, D.G.; Svensson, M.; Morokuma, K.; Strömberg, S.; Zetterberg, K.; Siegbahn, P.E.M. Density Functional Study of the Mechanism of the Palladium(II)-Catalyzed Ethylene Polymerization Reaction. Organometallics 1997, 16, 1933-1945. [CrossRef]

115. Froese, R.D.J.; Musaev, D.G.; Morokuma, K. Theoretical Study of Substituent Effects in the Diimine-M(II) Catalyzed Ethylene Polymerization Reaction Using the IMOMM Method. J. Am. Chem. Soc. 1998, 120, 1581-1587. [CrossRef]

116. Michalak, A.; Ziegler, T. DFT Studies on Substituent Effects in Palladium-Catalyzed Olefin Polymerization. Organometallics 2000, 19, 1850-1858. [CrossRef] 